\title{
Collagenous Alzheimer amyloid plaque component impacts on the compaction of amyloid- $\beta$ plaques
}

\author{
Tadafumi Hashimoto ${ }^{1,2^{*}+}$ (D), Daisuke Fujii ${ }^{\dagger \dagger}$, Yasushi Naka ${ }^{1 \dagger}$, Mayu Kashiwagi-Hakozaki ${ }^{1 \dagger}$, Yuko Matsuo $^{1}$, \\ Yusuke Matsuura ${ }^{3}$, Tomoko Wakabayashi ${ }^{1,2}$ and Takeshi Iwatsubo ${ }^{1,3^{*}}$
}

\begin{abstract}
Massive deposition of amyloid $\beta$ peptides (A 3 ) as senile plaques (SP) characterizes the brain pathology of Alzheimer's disease (AD). SPs exhibit a variety of morphologies, although little is known about the SP components that determine their morphology. Collagenous Alzheimer amyloid plaque component (CLAC) is one of the major non-A $\beta$ proteinaceous components of SP amyloid in AD brains. Here we show that overexpression of CLAC precursor (CLAC-P) in the brains of APP transgenic mice results in a significant remodeling of amyloid pathology, i.e., reduction in diffuse-type amyloid plaques and an increase in compact plaques laden with thioflavin S-positive amyloid cores. In vivo microdialysis revealed a significant decrease in A $\beta$ in the brain interstitial fluid of CLAC-P/APP double transgenic mice compared with APP transgenic mice. These findings implicate CLAC in the compaction of A $\beta$ in amyloid plaques and the brain dynamics of $A \beta$.
\end{abstract}

Keywords: Alzheimer's disease/amyloid, $\beta$ peptide/CLAC/senile plaques

\section{Introduction}

Senile plaques (SPs) are the pathological hallmark lesions in the brains of patients with Alzheimer's disease (AD), of which the major building blocks are amyloid fibrils composed of amyloid- $\beta$ peptides $(A \beta)[17]$. $A \beta$ is a proteolytic product of the sequential cleavage of $A \beta$ precursor protein (APP) by $\beta$ - and $\gamma$-secretases. Genetic evidence $[16,34]$, together with cellular and animal studies $[6,15$, $23,48]$, led to the amyloid hypothesis, which assumes that fibrillization and deposition of $A \beta$ is central to the

*Correspondence: tonchan@m.u-tokyo.ac.jp; iwatsubo@m.u-tokyo.ac.jp †Tadafumi Hashimoto, Daisuke Fujii, Yasushi Naka and Mayu KashiwagiHakozaki are co-first authors

${ }^{1}$ Department of Neuropathology, Graduate School of Medicine, The University of Tokyo, 7-3-1 Hongo, Bunkyo-ku, Tokyo 113-0033, Japan

Full list of author information is available at the end of the article pathogenesis of $\mathrm{AD}$ [41]. However, factors that trigger the process of $A \beta$ deposition remain yet to be characterized.

Morphologically, SPs are classified into several types [11, 12, 26, 57]: "Primitive" plaques are distinctly circumscribed structures without amyloid cores; "Typical" or "classical" plaques harbor amyloid cores at the center, and "burnt-out" plaques composed exclusively of the amyloid cores. Amyloid cores are stained by the dyes specifically bound to $\beta$-sheeted structures, e.g., thioflavin $\mathrm{S}(\mathrm{ThS})$. Swollen dystrophic neurites are associated with the primitive and typical plaques, which are interpreted as signatures of local amyloid toxicity [31, 42]. Some reports have suggested the correlation between the ThSpositive mature plaques and neurotoxicity and synaptic dysfunction in the brains of AD patients and APP transgenic $(\mathrm{tg})$ mice, implicating the role of mature plaques in the pathological progression of $\mathrm{AD}[43,52]$. In contrast to the "mature" plaques, "diffuse" plaques composed of amorphous $A \beta$ deposits that are negative for ThS and lack the association of dystrophic neurites [58]. Because

(c) The Author(s) 2020. This article is licensed under a Creative Commons Attribution 4.0 International License, which permits use, sharing, adaptation, distribution and reproduction in any medium or format, as long as you give appropriate credit to the original author(s) and the source, provide a link to the Creative Commons licence, and indicate if changes were made. The images or other third party material in this article are included in the article's Creative Commons licence, unless indicated otherwise in a credit line to the material. If material is not included in the article's Creative Commons licence and your intended use is not permitted by statutory regulation or exceeds the permitted use, you will need to obtain permission directly from the copyright holder. To view a copy of this licence, visit http://creativeco mmons.org/licenses/by/4.0/. The Creative Commons Public Domain Dedication waiver (http://creativecommons.org/publicdomain/ zero/1.0/) applies to the data made available in this article, unless otherwise stated in a credit line to the data. 
diffuse plaques are observed at the earliest stage of $A \beta$ deposition during the progression of AD pathology [24, 25 ], they are considered as the most "immature" form of $\mathrm{A} \beta$ deposits. However, specific components of amyloid deposits that determine the SP morphology remain unidentified.

We have previously identified CLAC (collagenous Alzheimer amyloid plaque component) in SPs of AD brains [18]. CLAC is a proteolytic fragment cleaved by furin convertase from a membrane-spanning collagen CLAC-P (CLAC precursor)/collagen type XXV $\alpha 1$ chain (COL25A1), the latter being shown to play a crucial role in intramuscular motor innervation during neuromuscular development [35, 50]. Genetically, SNPs in COL25A1 gene have been shown to be associated with $\mathrm{AD}$ in a Swedish cohort [14], and rare coding variants in COL25A1 gene were identified in the longevity population of the Wellderly healthy aging cohort [13]. These genetics findings also led us to hypothesize that CLAC is involved in the pathogenesis of AD.

CLAC exhibits a unique pattern of distribution in $\mathrm{AD}$ brains: primitive SPs and the peripheral portion of typical SPs are strongly positive for CLAC, whereas diffuse plaques, cerebral amyloid angiopathies and the core portion of typical SPs are CLAC-negative [27]. A number of proteomics analyses also revealed the existence of CLAC in the isolated SP fractions $[28,29,45]$, formic-acidextracts [55], or sarkosyl-insoluble-extracts [2] of $\mathrm{AD}$ brains. These results support the view that CLAC may be involved in the morphological variation of SPs in AD brains.

In this study, we attempted to verify this hypothesis in tg mice overexpressing human CLAC-P and human APP. In the brains of APP/CLAC-P double tg mice, diffuse $A \beta$ plaques were replaced by compact $A \beta$ plaques, and in vivo microdialysis revealed a significant decrease in the levels of $A \beta$ in the brain interstitial fluid. These results support the notion that co-deposition of CLAC with $A \beta$ elicits the remodeling of amyloid deposition into compact plaques, thereby altering the dynamics of $A \beta$ in the brain.

\section{Materials and methods \\ Experimental design}

Heterozygous CLAC-P tg mice and APP tg mice were crossed with C57BL/6J wild-type mice. All mice analyzed in this paper were $\mathrm{F} 1$ progeny derived from a single cross between heterozygous CLAC-P tg mice and heterozygous APP tg mice. The whole brains ware removed from the skull, bisected along the sagittal plane, and the right hemisphere was immediately frozen in liquid nitrogen for biochemical analyses and the left hemisphere was immediately fixed in $50 \mathrm{mM}$ phosphate buffer containing
4\% paraformaldehyde $\mathrm{pH} 7.4$ for immunohistochemical analyses. For the analyses of J20 $\times$ CLAC mice, we analyzed 9 mice (3 female, 6 male) for 3-month-old, 31 mice ( 21 female, 10 male) for 6 -month-old, 18 mice ( 6 female, 12 male) for 9-month-old, 40 mice ( 15 female, 25 male) for 12-month-old, and 24 mice (9 female, 15 male) for 15 -month-old. For the analyses of A7 $\times$ CLAC mice, we analyzed 48 mice ( 26 female, 22 male) for 18-22-monthold, and 8 mice ( 8 male) for 5-7-month-old. Detailed genotype of those mice was described in the corresponding figure legend.

\section{Animals}

Human full-length CLAC-P cDNA [18] was subcloned into the XhoI site of exon 3 of the Thy 1.2 expression cassette. Linearized cDNA by NotI digestion was purified and microinjected into pronuclei of single-cell embryos derived from hybrid mice between C57BL/6N male $\times$ BDF1 female (Oriental Yeast). CLAC-P tg mice were identified and genotyped by genomic PCR analyses of tail DNA using specific primers: thyfw $25^{\prime}$-aggtattcatcatgtgctcc- $3^{\prime}$ and clnc1rev $5^{\prime}$-atcaggcagcagatgaatgg- $3^{\prime}$ (407 base-pairs DNA is amplified). APP tg mice (J20 line) were purchased from Jackson Laboratory and genotyped according to the breeder's protocol. APP tg mice (A7 line) were generated previously [56] and genotyped using specific primers: TgF1 $5^{\prime}$-ctgaggtattcatcatgtgc- $3^{\prime}$ and $\mathrm{TgR} 3$ $5^{\prime}$-ggacattcatgtgcatgttc- $3^{\prime}$ (336 base-pairs DNA is amplified). All mice were kept under SPF conditions and fed a regular diet (Oriental Yeast).

\section{RT-PCR}

Mouse tissues were extracted by Isogen (NIPPON GENE) and reverse-transcribed as described [18]. RT-PCR analysis was performed by SuperScript II One-step RT-PCR with PLATINUM Taq (Thermo Fisher Scientific) using human CLAC-P specific primers: forward 5 -tccattcatctgctgcctgataccc- $3^{\prime}$ and reverse $5^{\prime}$-tcaggcggcgtttaatgagctgctg- $3^{\prime}$ (321 base-pairs DNA is amplified).

\section{Antibodies}

Polyclonal antibodies against human CLAC-P were previously described [18]. A monoclonal antibody $82 \mathrm{E} 1$ is a human $\mathrm{A} \beta \mathrm{N}$-terminal-end specific antibody (ImmunoBiological Laboratories). A monoclonal antibody BAN50 against human APP and A $\beta$ were described $[1,48]$. A monoclonal antibody $6 \mathrm{E} 10$ against human APP and A $\beta$ was purchased from BioLegend. A monoclonal antibody against ubiquitin was purchased from DAKO. A polyclonal antibody against RFP was purchased from MBL. A polyclonal antibody against Iba1 was purchased from Wako. Primary antibodies were applied at dilutions of 
1:200 for anti-NC1; 1:100 for anti-NC2-2; 1:1000 for antiNC3 and anti-NC4; 1:500 for anti-pyroE113; 1:100 for 82E1; 1:5000 for BAN50; 1:1000 for 6E10; 1:500 for antiubiquitin; 1:1000 for anti-RFP; 1:500 for anti-Iba1.

\section{Immunoblot analysis and two-site enzyme-linked immunosorbent assay (ELISA)}

Hemispheres of mouse brains were homogenized in 10 volumes (w/v) of TBSI buffer $(50 \mathrm{mM}$ Tris- $\mathrm{HCl} \mathrm{pH} \mathrm{7.6,}$ $150 \mathrm{mM} \mathrm{NaCl}, 0.5 \mathrm{mM}$ diisopropyl fluorophosphates, $0.5 \mathrm{mM}$ phenylmethylsulfonyl fluoride, $1 \mathrm{mM}$ EGTA, $1 \mu \mathrm{g} / \mathrm{ml}$ antipain, $1 \mu \mathrm{g} / \mathrm{ml}$ leupeptin, $1 \mu \mathrm{g} / \mathrm{ml}$ pepstatin, $1 \mu \mathrm{g} / \mathrm{ml} \mathrm{N \alpha}$-Tosyl- ${ }_{\mathrm{L}}$-lysine chloromethyl ketone, or $50 \mathrm{mM}$ Tris- $\mathrm{HCl} \mathrm{pH} 7.6,150 \mathrm{mM} \mathrm{NaCl}$, with a cOmplete protease inhibitors cocktail (Roche)), and centrifuged at $260,000 \times \mathrm{g}$ for $20 \mathrm{~min}$ at $4{ }^{\circ} \mathrm{C}$. The supernatant was used as a TBS-soluble fraction or a cytosolic fraction. The pellet was homogenized again in 10 volumes $(\mathrm{w} / \mathrm{v})$ of TBSI buffer containing $2 \%$ Triton X-100 and centrifuged at $260,000 \times g$ for $20 \mathrm{~min}$ at $4{ }^{\circ} \mathrm{C}$. The supernatant was used as a membrane fraction. The pellet was homogenized again in 10 volumes $(\mathrm{w} / \mathrm{v})$ of TBSI buffer containing $2 \%$ SDS, incubated at $37{ }^{\circ} \mathrm{C}$ for $30 \mathrm{~min}$ and centrifuged at $260,000 \times g$ for $20 \mathrm{~min}$ at $20^{\circ} \mathrm{C}$. The SDSinsoluble pellet was dissolved in $1 \mathrm{ml}$ of $70 \%$ formic acid, centrifuged at $260,000 \times g$ for $20 \mathrm{~min}$ at $4{ }^{\circ} \mathrm{C}$. The formic acid-soluble fraction was desiccated by Speed-Vac and then resuspended 1 volume (w/v) of dimethyl sulfoxide (DMSO). The DMSO-soluble fraction was used as a SDSinsoluble fraction. SDS-PAGE was performed as previously described [18], under a reducing condition. The immunoblots were developed using Immunostar reagents (Wako) or SuperSignal west femto (Thermo Fisher Scientific) and visualized by LAS-1000plus (FUJIFILM). The intensity of the band was quantified by Image Gauge software (FUIIFILM). The amount of TBS-soluble or SDS-insoluble human $A \beta$ was quantified using a Human/ Rat $A \beta 40$ or $A \beta 42$ specific two-site ELISA (BNT77/BA27 for $A \beta 40$ or $B N T 77 / B C 05$ for $A \beta 42$, FUJIFILM Wako) as previously described [51].

\section{Immunohistochemistry and ThS staining}

Mice hemispheres were immediately fixed in $50 \mathrm{mM}$ phosphate buffer containing $4 \%$ paraformaldehyde $\mathrm{pH}$ 7.4 for $24 \mathrm{~h}$. The paraffin-embedded sections cut at $5 \mu \mathrm{m}$ were de-paraffinized in xylene and rehydrated through an ethanol dilution series. For immunostaining of $A \beta$, the sections were pretreated microwave $(550 \mathrm{~W})$ in citrate buffer pH 6.0 for $10 \mathrm{~min}$, following reaction with $100 \mu \mathrm{g} /$ $\mathrm{ml}$ of Proteinase $\mathrm{K}$ (Worthington) in Tris-buffered saline (TBS) $\mathrm{pH} 7.6$ for $7 \mathrm{~min}$. For immunostaining of CLAC, the sections were pretreated microwave as above. Primary antibodies were treated for $12 \mathrm{~h}$. HRP-conjugated anti-mouse or anti-rabbit antibody was used as a secondary antibody (Vector Laboratories). The paraffin sections were then visualized with VECTASTAIN ABC elite system (Vector Laboratories) using diaminobenzidine [27]. Images were captured by HC-2500 digital image recording system (FUIFILM) mounted on a BX51 microscope (Olympus). The mean area of amyloid burden in hippocampus stained by BAN50 or 82E1 from 3 images per an animal was measured using MacSCOPE software (Mitani). The mean number of ubiquitin-positive plaques in hippocampus from 3 images per an animal was also quantified using MacSCOPE software. The mean plaque size or circularity of each $A \beta$ plaque in the hippocampus was quantified using Image J software. For ThS staining, the paraffin sections were de-paraffinized, rehydrated and stained in $1 \% \mathrm{ThS}$ (Sigma) containing distilled water for $10 \mathrm{~min}$. In double-labeling experiments for CLAC and $\mathrm{ThS}$, paraffin sections were fluorescent-labeled by anti-NC2-2, followed by ThS staining. ThS images were observed with Olympus fluoview confocal microscope as described [27] and captured by DP70 digital image recording system (Olympus). The mean number of ThSpositive plaques in hippocampus from 3 images per an animal was quantified using MacSCOPE software.

\section{Adeno-associated virus serotype 9 (AAV9)-mediated expression of CLAC-P}

pAAV.hSyn.EGFP.WPRE.bGH vector is a gift from James M. Wilson (Addgene plasmid \#105539; http:// n2t.net/addgene:105539; PRID:Addgene_105539). The cDNA encoding nuclear localization signal-tagged dTomato-P2A-3xFLAG-tagged CLAC-P fusion protein was substituted into EGFP sequence in the pAAV.hSyn. EGFP.WPRE.bGH vector that carries human Synapsin I promoter. The packing, purification, or titer determination of AAV9-CLAC-P was performed by the PENN Vector Core. The stereotaxic injection of AAV9-CLAC$\mathrm{P}$ into cortex and hippocampus of APP tg mice was performed as described [22]. Briefly, $1 \mu \mathrm{l}$ of AAV9-CLAC-P $\left(5.0 \times 10^{12}\right.$ genome copy $\left./ \mathrm{ml}\right)$ solution or phosphatebuffered saline (PBS) was injected into the hippocampus (anterior-posterior $-2.5 \mathrm{~mm}$, medial-lateral $\pm 2.0 \mathrm{~mm}$, dorsal-ventral $-1.8 \mathrm{~mm}$ from Bregma) and the cortex (anterior-posterior $-2.5 \mathrm{~mm}$, medial-lateral $\pm 2.0 \mathrm{~mm}$, dorsal-ventral - $1.0 \mathrm{~mm}$ from Bregma) in 14-month-old APP tg mice at a rate of $0.1 \mu \mathrm{L} / \mathrm{min}$. After four months from injection, AAV-injected mice were analyzed by immunohistochemistry or ThS staining.

\section{In vivo microdialysis}

In vivo microdialysis was performed as previously [59]. Briefly, a microdialysis cannula (Eicom) was inserted stereotaxically into the hippocampal area of APP tg mice 
(A7 line) or APP/CLAC-P double tg mice filled with artificial cerebrospinal fluid (aCSF; $1.3 \mathrm{mM} \mathrm{CaCl}_{2} .1 .2 \mathrm{mM}$ $\mathrm{MgSO}_{4}, 3.0 \mathrm{mM} \mathrm{KCl}$. 0.4 mM KH $\mathrm{PO}_{4}, 25 \mathrm{mM} \mathrm{NaHCO}_{3}$, $122 \mathrm{mM} \mathrm{NaCl}$ ) containing $0.15 \%$ bovine serum albumin through a cranial hole $2.8 \mathrm{~mm}$ posterior and $0.5 \mathrm{~mm}$ lateral to the right side from the bregma, with an angle of $37.5^{\circ}$ to the depth of $1.3 \mathrm{~mm}$, and set with a dialysis probe of molecular-weight cut-off at $1,000 \mathrm{kDa}$ (Eicom). aCSF was circulated at the rate of $1.3 \mu \mathrm{l} / \mathrm{min}$ and sampling was started after $3 \mathrm{~h}$, with mice in a free moving cage. Levels of $A \beta 42$ in ISF were quantified by a Human/Rat A 342 specific two-site ELISA (BNT77/BC05, FUJIFILM Wako).

\section{Statistical analyses}

Tests for statistical significance between groups were performed using StatView software (SAS) or Prism 6 (GraphPad). In experiments involving two groups, Mann-Whitney U test for non-parametric tests, and Student's $t$ test, paired $\mathrm{t}$-test, or Welch's $\mathrm{t}$-test for parametric tests were performed. The details and results of all statistical tests are described in the corresponding figure legend for each experiment.

\section{Results}

\section{Overexpression of CLAC-P did not alter the expression} and processing of APP in the brains of APP/CLAC-P double tg mice

To elucidate the pathological roles of CLAC in vivo, we generated tg mice overexpressing human CLAC-P (CLAC-P tg) in a neuron-specific manner under murine Thy1.2 promoter (Fig. 1a) [47, 54]. We examined the expression levels of human CLAC-P protein in the brains of F2 generation derived from eight F0 founders by immunoblotting and immunohistochemistry, and obtained two high-expressor lines, of which we used the line \#74 throughout the study. Human CLAC-P mRNA was expressed in the central nervous system of CLAC-P tg mice (Fig. 1b), and human CLAC-P protein was recovered from the membrane fraction of the brain (Fig. 1c). We previously showed that CLAC-P is cleaved by furin convertase after the domain ${ }_{107} \mathrm{KIRIAR}_{112}$ to release its extracellular domain as a secreted form of CLAC$\mathrm{P}$ (sCLAC), which co-deposits with $\mathrm{A} \beta$ in $\mathrm{AD}$ brains as CLAC [18]. We also found that the amino terminus of CLAC deposited in AD brains underwent pyroglutamate modification [18]. To confirm whether CLAC is secreted in the brains of CLAC-P $\operatorname{tg}$ mice, we immunostained slices of brains from CLAC-P tg or wild-type mice using multiple anti-CLAC-P antibodies that specifically recognize the intracellular domain (anti-NC1), extracellular domain (anti-NC4), or the pyroglutamate modified $\mathrm{E}_{113}$ (anti-pyroE113) (Fig. 1d). We found that overproduced
CLAC-P proteins were localized in neuronal cell bodies throughout the central nervous system of CLAC-P tg mice (Fig. 1e). Notably, tiny plaque-like structures that are positively labeled by anti-NC4 as well as by antipyroE113 antibodies, but not by anti-NC1 antibody, were found in the neocortices of CLAC-P tg mice over the age of 3-month-old (Fig. 1e). Such plaque-like structures were not observed by immunostaining with anti-NC4 and anti-pyroE113 antibodies in the brains of wild-type mice (Fig. 1e). These observations suggest that CLAC is secreted from neurons and forms aggregates in the extracellular space of brain parenchyma of CLAC-P tg mice.

To elucidate the effects of CLAC on AD-related pathology in vivo, we crossed CLAC-P tg mice with APP tg mice, which express human APP in neurons and exhibit AD-like amyloid pathology in the brain. For this purpose, we used two lines of APP tg mice, J20 and A7. J20 expresses human APP carrying the Swedish and Indiana mutations (KM670/671NL+V717F) driven under the control of platelet-derived growth factor $\beta$-chain promoter [33], and A7 expresses human APP carrying the Swedish and Austrian mutations (KM670/671NL+ T714I) under the control of Thy1.2 promoter [56]. F1 progeny derived from a single cross between heterozygous CLAC-P tg mice and heterozygous APP tg mice was used throughout the study.

Immunoblotting of the brain lysates showed comparable levels of human APP between APP single tg mice (J20 or A7 line) and APP/CLAC-P double tg (double tg) mouse littermates (Fig. 1f (J20 line), 1g, 1h (A7 line), 1i). APP undergoes proteolytic cleavage by ectodomain sheddases, i.e., $\alpha$-secretase or $\beta$-secretase, followed by intramembrane cleavage by $\gamma$-secretase. We found that the amounts of the carboxy-terminal fragments (CTFs) of APP by $\alpha$-secretase (CTF- $\alpha$ ) or $\beta$-secretase (CTF- $\beta$ ) cleavage in the membrane fractions of mouse brains were at similar levels (Fig. $1 \mathrm{j}$ (J20 line), $1 \mathrm{k}$ ). These data suggest that co-expression of additional single-span membrane protein, CLAC-P, does not affect the expression and processing of APP in the brains of the double tg mice.

\section{Overexpression of CLAC-P altered the morphology of $A \beta$ plaques in the brains of double tg mice}

We next examined the histopathology of brains of the APP (J20 line) and double tg mice with special attention to the morphology and distribution of $A \beta$ plaques. We immunostained the tissue sections from brains of $6,9,12$ and 15-month-old APP tg and their littermate double tg mice by an anti-A $\beta$ antibody $82 \mathrm{E} 1$. At 6 months of age, a few $A \beta$ plaques appeared at the dentate gyrus, $C A 1$ and $\mathrm{CA} 3$ regions in the hippocampus of APP and double tg mice in an almost similar pattern (Fig. 2a, e), consistent with the previous description that $A \beta$ plaques are initially 
a

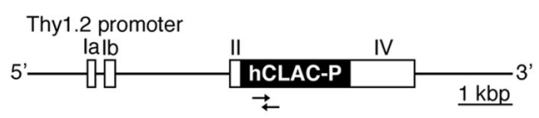

b

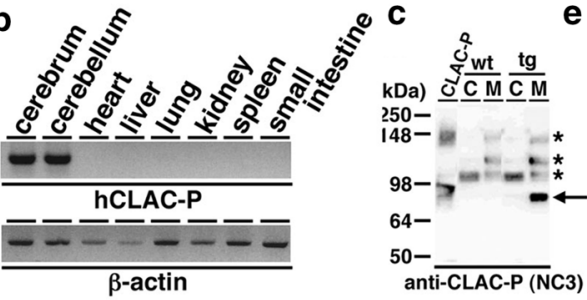

f

APP tg (J20) + + + - + + - -

CLAC-P tg -++-++-+-

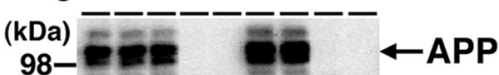

64ーーニニーーニーニー СLAC-P

g

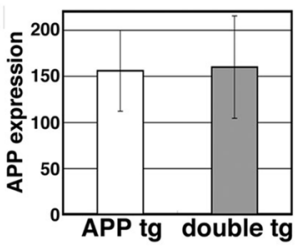

h

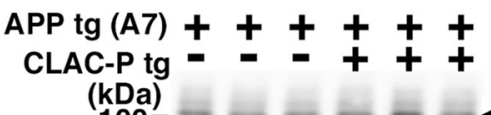

(kDa) $-\cdots-\cdots$ APP

i

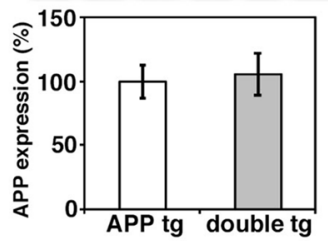

e d cytosol extracellular

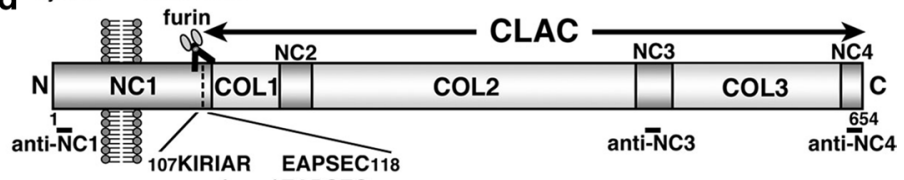
(pyro)EAPSEC
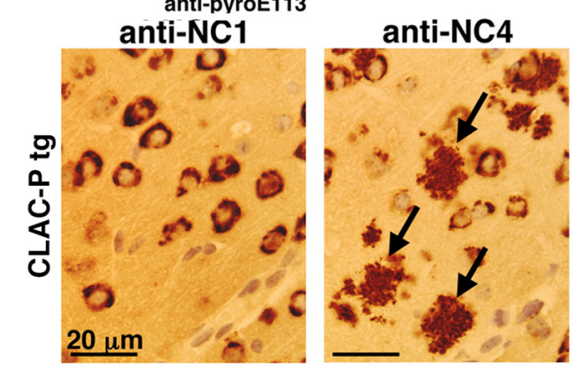

anti-pyroE113
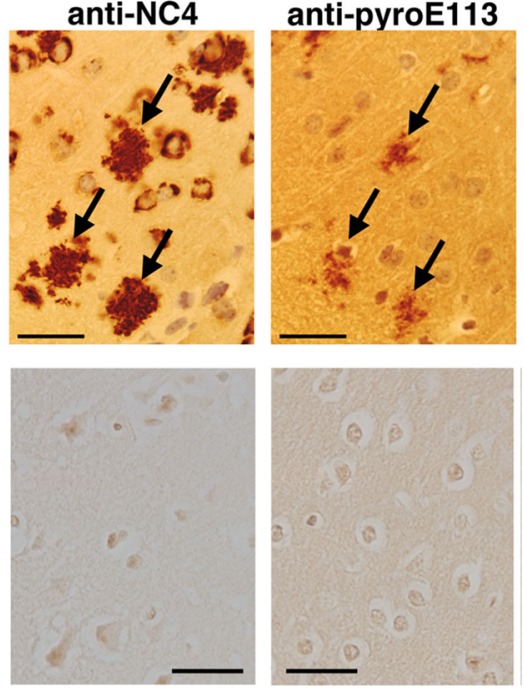

j $\operatorname{APP} \operatorname{tg}(\mathrm{J} 20)++++$

CLAC-P tg --++

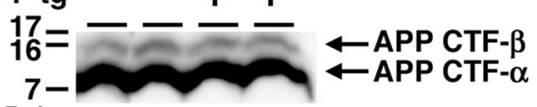

(kDa)

k

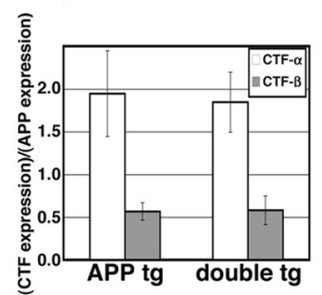

Fig. 1 Generation of CLAC-P tg mice and APP/CLAC-P double tg mice. a A schematic structure of human CLAC-P (hCLAC-P) transgene using murine Thy 1.2 promoter. The arrows show the location of human CLAC-P specific primers. Scale bar shows $1 \mathrm{kbp}$. b RT-PCR analyses in CLAC-P tg mice (line\#74) using human CLAC-P (upper panel) and murine $\beta$-actin (lower panel) specific primers. c Immunoblot analysis of the brains of CLAC-P tg and its littermate wild-type mice (wt). Mice brains were extracted sequentially by Tris saline (cytosolic fraction, C) and 2\% Triton X-100 (membrane fraction, M). Arrow shows the mobility of CLAC-P in HEK293 cells. Asterisks show the non-specific bands. $\mathbf{d}$ Schematic representation of the domain structure of human CLAC-P. The NC1 domain composed of cytoplasmic, transmembrane and extracellular portions, three extracellular non-collagenous domains (NC2, NC3 and NC4) and the three collagenous domains (COL1, COL2 and COL3) are shown. The epitope locations of the antibodies are shown in black bars. e Immunohistochemical analyses of cerebral cortex of 6-month-old CLAC-P tg (upper panels) or wild-type mice (lower panels) by anti-NC1, NC4, and pyroE1 13 human CLAC-P specific antibodies. The plaque-like structures are exclusively positive for the extracellular epitope of CLAC-P (arrows). Scale bar shows $20 \mu \mathrm{m}$. $\mathbf{f}, \mathbf{h}$ Immunoblots of human APP and human CLAC-P in membrane fraction of the brains of double (J20 (f), A7 (h)) tg mice by anti-human APP antibody (BAN50 upper panel in $\mathbf{f}, 6$ E10 in $\mathbf{h}$ ), or anti-CLAC-P antibody (anti-NC4 lower panel in (h)). $\mathbf{g}$ Densitometric analyses of the levels of full-length APP in the brains of APP (J20) and double tg mice. The mean \pm SD N=6 (APP), 7 (double). Student's t-test, $p=0.89$. i Densitometric analyses of the levels of full-length APP in the brains of APP (A7) and double tg mice. The mean \pm SD is shown. $N=13$ (APP), 9 (double). Student's t-test, $p=0.90$. $\mathbf{j}$ Immunoblot analysis of the APP CTFs (APP CTF-a and APP CTF- $\beta$ ) in the brains of APP (J20) and double tg mice by anti-APP C-terminus. $\mathbf{k}$ Densitometric analyses of the levels of APP CTFs (normalized by the levels of full-length APP). The mean \pm SD N=4 (APP), 3 (double) tg. Student's t-test, $p=0.58$ (APP CTF- $a$ ) and 0.71 (APP CTF- $\beta$ ) 


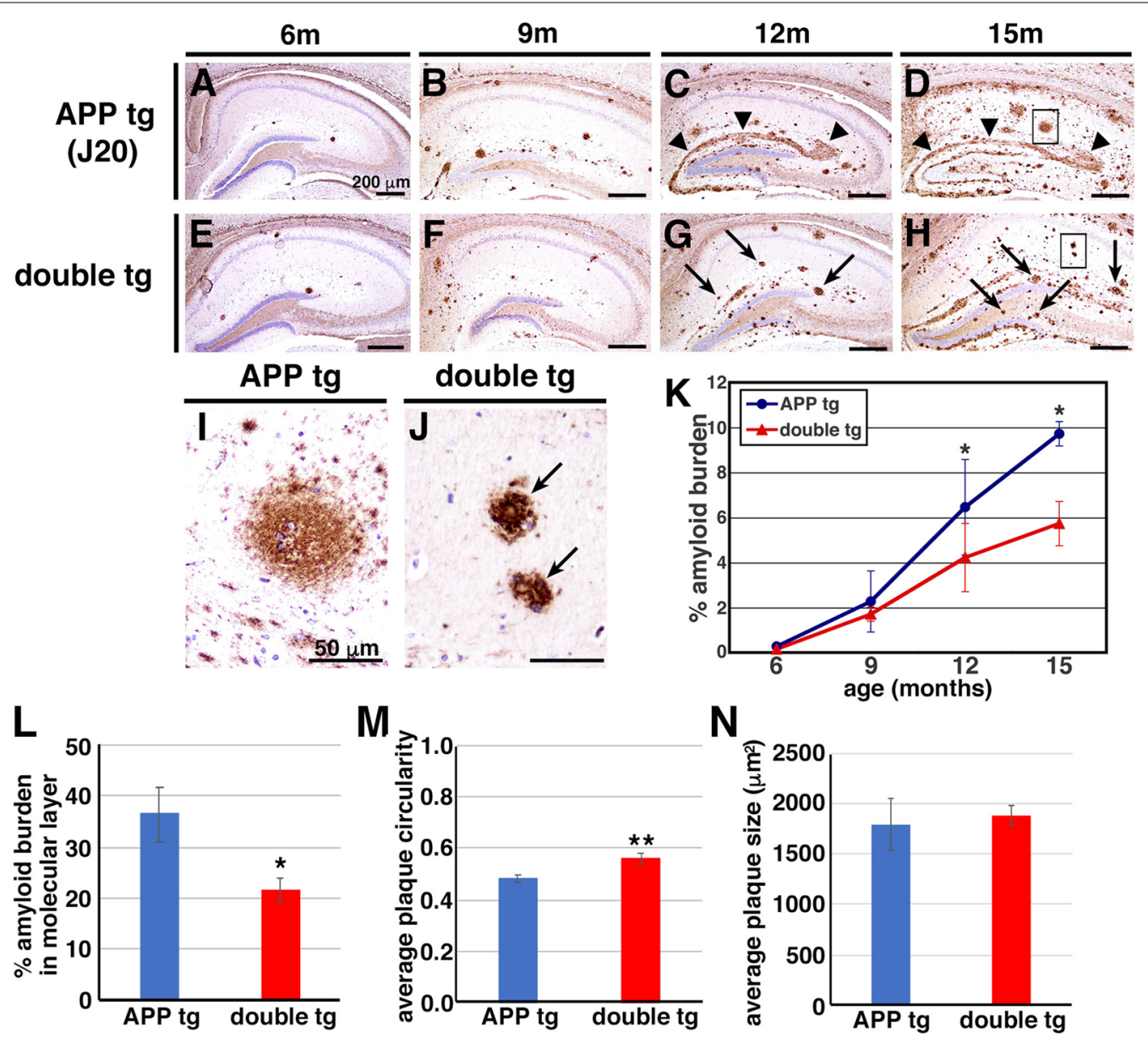

Fig. 2 Overexpression of CLAC-P altered the morphology of A $\beta$ deposits ( 20 line). $\mathbf{a}-\mathbf{h}$ Immunohistochemical analyses of the brains of 6 - (a and e), 9- (b and f), 12- (c and $\mathbf{g}$ ) and 15-( $\mathbf{d}$ and $\mathbf{h}$ ) month-old APP tg mice (J20 line, a-d) and double tg mice (e-h) using an anti-human A 3 antibody (82E1). High magnification images (insets in $\mathbf{d}$ and $\mathbf{h}$ ) were shown in $\mathbf{i}$ and $\mathbf{j}$, respectively. Diffuse amyloid plaques (c and $\mathbf{d}$, arrowheads) and huge plaques (i) were shown in the hippocampi of APP tg mice. On the other hand, numerous middle-sized plaques were predominant in the hippocampi of 12- and 15-month-old double tg mice ( $\mathbf{g}, \mathbf{h}$ and $\mathbf{j}$, arrows). Scale bar shows $200 \mu \mathrm{m}(\mathbf{a}-\mathbf{h})$ and $50 \mu \mathrm{m}$ (i and $\mathbf{j})$. $\mathbf{k}$ Quantitative analysis of the amyloid burden (\%A $\beta$ immunoreactive areas) in the hippocampus of APP and double tg mice. N=4, 4, 13, 7 for 6-, 9-, 12-, 15-month-old APP $\operatorname{tg}$, respectively. $N=6,3,11,7$ for 6-, 9-, 12-, 15-month-old double tg, respectively. Mann-Whitney $U$ test, $p=0.29$ (6-month-old), 0.48 (9-month-old) 0.019 (12-month-old), 0.018 (15-month-old). I Quantitative analysis of the amyloid burden at the molecular layer of hippocampal dentate gyrus of 15-month-old APP and double tg mice. $N=6$ (APP tg) and 7 (double tg). Student's t-test, $p=0.024,{ }^{*}, p<0.05$ ( $\left.\mathbf{m}, \mathbf{n}\right)$ Average circularity (m) and size (n) of A $\beta$ plaques in the hippocampus of 15-month-old APP and double tg mice. Note that Circularity value of 1.0 indicates a perfect circle. $\mathrm{N}=6$ (APP tg) and 7 (double tg). Student's t-test, $p=0.0076,{ }^{*}, p<0.01$ (n) N=6 (APP tg) and 7 (double tg). Student's t-test, $p=0.76$

detected in the hippocampus of J20 line at 5-7 months of age [33], suggesting that overexpression of CLAC-P does not influence the onset age of $A \beta$ deposition. After 12 months of age, there emerged a clear difference in the pattern of amyloid deposition between APP and double tg mice: in the hippocampus of APP tg mice, diffuse-type $A \beta$ plaques were observed in a laminar pattern in the molecular layer of the dentate gyrus, whereas diffuse $A \beta$ plaques were rarely observed in the hippocampal area of double tg mice (Fig. 2c, d, g, h). In addition, a few round and well-circumscribed, huge $\mathrm{A} \beta$ plaques $(>50-100 \mu \mathrm{m}$ in diameter) were observed in the hippocampus of APP tg mice (Fig. 2i). In sharp contrast, middle-sized $A \beta$ plaques $(<50 \mu \mathrm{m}$ in diameter) reminiscent of primitivetype plaques in $\mathrm{AD}$ brains, or middle-sized $\mathrm{A} \beta$ plaques occasionally laden with amyloid cores resembling typical mature plaques in $\mathrm{AD}$ brains, were predominantly observed in the hippocampal region of double tg mice (Fig. 2j). Quantification of the amyloid burden (percent area covered by $A \beta$ immunoreactivity) of the hippocampus showed that the burden was significantly smaller in the double tg mice by $35 \%$ at $12 \mathrm{M}$ (mean values: $6.46 \%$ 
in APP and $4.22 \%$ in double tg mice) and by $41 \%$ at $15 \mathrm{M}$ (mean values: $9.72 \%$ in APP and $5.73 \%$ in double tg mice) compared with those in APP tg mice (Fig. 2k). Especially, the amyloid burden at the molecular layer of hippocampal dentate gyrus, where diffuse-type plaques were predominant, was significantly smaller in the double tg mice by $\sim 41 \%$ at $15 \mathrm{M}$ (mean values: $36.4 \%$ in APP and $21.7 \%$ in double tg mice) (Fig. 2l). It has been documented that compact plaques yield a higher circularity compared with diffuse-type plaques in the brains of APP $\operatorname{tg}$ mice (circularity value of 1.0 indicates a perfect circle) [60]. Further detailed observation of the morphology of individual plaques revealed that the mean circularity in plaques in the brains of double tg mice was significantly higher than that of APP tg mice (mean values: 0.48 in APP and 0.56 in double tg mice) (Fig. $2 \mathrm{~m}$ ), without significant differences in the mean plaque size (mean values: $1799 \mu \mathrm{m}^{2}$ in APP and $1889 \mu^{2}$ in double tg mice) (Fig. 2n). These results suggest that overexpression of CLAC-P decreased the total area (i.e., amyloid burden) of $A \beta$ deposits, and altered the plaque morphology from diffuse-type to well-circumscribed, compact plaques.

We further generated an additional line of double tg mice by crossing CLAC-P tg mice with another type of APP tg mice (A7 line). In the brains of 18-month-old APP tg mice and their littermate double tg mice, $A \beta$ plaques were observed both in the cortex area of APP and double tg mice (Fig. 3a, b). Similarly to J20-based double tg line, middle-sized, well-circumscribed $A \beta$ plaques that were occasionally associated with amyloid cores were predominant and the diffuse-type plaques were hardly observed in the cortex of double tg mice. The amyloid burden in the piriform cortex of double tg mice was significantly smaller compared with those in APP tg mice (Fig. 3c). Furthermore, the amyloid burden at the molecular layer of hippocampal dentate gyrus was significantly smaller in the double tg mice by $76 \%$ (mean values: $17.6 \%$ in APP and $4.30 \%$ in double tg mice) (Fig. 3d). The mean circularity in plaques in the brains of double tg mice was significantly higher than that of APP tg mice (mean values: 0.40 in APP and 0.49 in double tg mice) (Fig. 3e), and
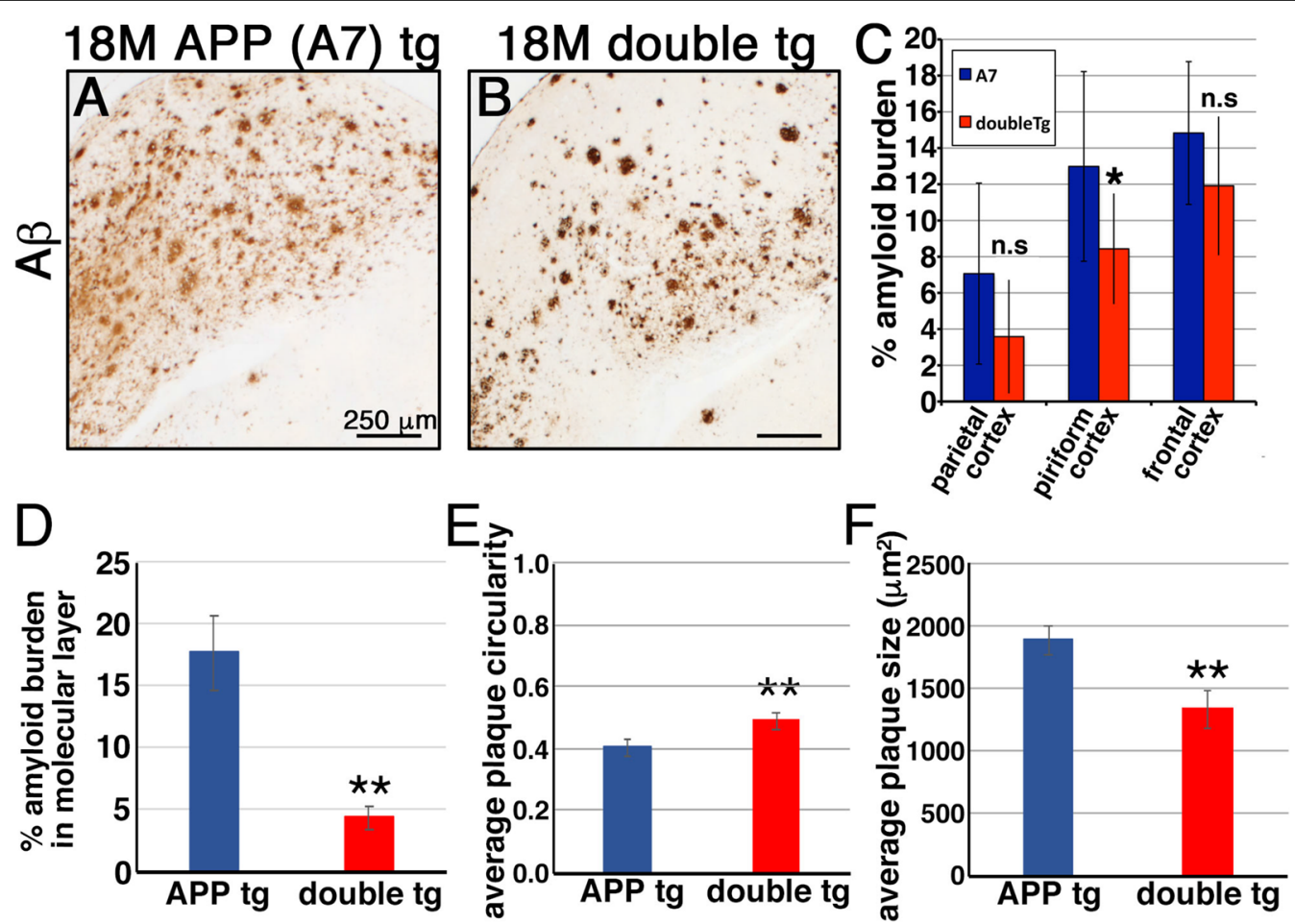

Fig. 3 Overexpression of CLAC-P altered the morphology of A $\beta$ plaques (A7 line). $\mathbf{a}, \mathbf{b}$ Immunohistochemical analyses of the entorhinal cortex of 18-month-old APP tg (A7, A) and double tg (A7 × CLAC-P, B) mice using an anti-human A 3 antibody (82E1). Scale bar shows $250 \mu m$. c Quantitative analysis of the amyloid burden (\% A $\beta$ immunoreactive areas) in the parietal cortex, piriform cortex and frontal cortex of APP tg and double tg mice. $\mathrm{N}=4$, Student's t-test, $p=0.069$ (parietal cortex), 0.024 (piriform cortex), 0.10 (frontal cortex), ${ }^{*} p<0.05$. $\mathbf{d}$ Qantitative analysis of the amyloid burden at the molecular layer of hippocampal dentate gyrus of 18-month-old APP and double tg mice. e N=15 (APP tg) and 12 (double tg). Student's t-test, $p=0.00061,{ }^{*}, p<0.01$. e, $\mathbf{f}$ Average circularity (e) and size (f) of A $\beta$ plaques in the hippocampus of 18-month-old APP and double tg mice. $\mathrm{N}=15$ (APP tg) and 12 (double tg). Student's t-test, $p=0.0061,{ }^{* *}, p<0.01$ (f) $\mathrm{N}=15$ (APP tg) and 12 (double tg). Student's t-test, $p=0.0046,{ }^{* *}$, $p<0.01$ 
the mean plaque size in double tg mice was significantly smaller than that in APP tg mice (mean values: $1891 \mu \mathrm{m}^{2}$ in APP and $1336 \mu \mathrm{m}^{2}$ in double tg mice) (Fig. 3f). Thus, similar changes in the total $A \beta$-positive area and plaque morphology were observed in the double tg mice based on distinct types of APP tg mice, i.e., a substantial decrease in the diffuse-type $A \beta$ plaques and the appearance of middle-sized compact $A \beta$ plaques occasionally with amyloid cores. This strongly suggested that the overexpression of CLAC-P altered the morphology of $A \beta$ plaques into a more compact form.

\section{Co-deposition of CLAC with $A \beta$ plaques in the brains of double tg mice}

CLAC has been identified as an SP amyloid component in $\mathrm{AD}$ brains [18]. To examine whether overexpressed CLAC co-deposits with $A \beta$ plaques in the brain, we immunostained serial sections from 12-months-old APP $\operatorname{tg}$ (J20 line) and their littermate double tg mice by anti-A $\beta$ (BAN50) and anti-CLAC-P (anti-NC4) antibodies. We found that $A \beta$ plaques in APP tg mice were weakly immunoreactive for endogenous CLAC (Fig. 4a, b), as previously observed in the brains of aged PS1/ APP mice [27]. Numerous A $\beta$ plaques in the hippocampus of double tg mice, especially most of the middlesized compact plaques, were strongly positive for CLAC (Fig. 4c-f). Notably, within the core-positive plaques, the peripheral region was CLAC-positive, whereas the amyloid cores were devoid of CLAC immunoreactivities (Fig. 4e, f). Cerebrovascular amyloid deposits in the double tg mice also were CLAC-negative (data not shown). The patterns of distribution of CLAC in $A \beta$ plaques were strikingly similar to those in $\mathrm{AD}$ brains $[18,27]$, supporting the notion that the interaction of CLAC with $A \beta$ amyloid modifies the distribution and morphology of $\mathrm{A} \beta$ plaques in the brains of double tg mice, and possibly, senile plaques in the brains of patients with $\mathrm{AD}$.

\section{Overexpression of CLAC-P promoted the maturation of $A \beta$ plaques in the brains of double tg mice}

To further examine the maturation of CLAC-positive $A \beta$ plaques, we stained brains of 9 to 15 -months-old APP tg (J20 line) and their littermate double tg mice with ThS (Fig. 5a, b), and found an age-dependent increase in the total numbers of ThS-positive $A \beta$ plaques in the hippocampus of both APP single and double tg mice (Fig. 5c). Notably, numerous small-sized ThS-positive structures were visualized in the hippocampus of double tg mice at 15 months of age (Fig. 5d), which corresponded to the core region of compact plaques (Fig. 5e). The average number of ThS-positive plaques in the hippocampus was significantly higher in the double tg mice by $\sim 2.65$ times at $12 \mathrm{M}$ (mean number per section, 26.7 in APP

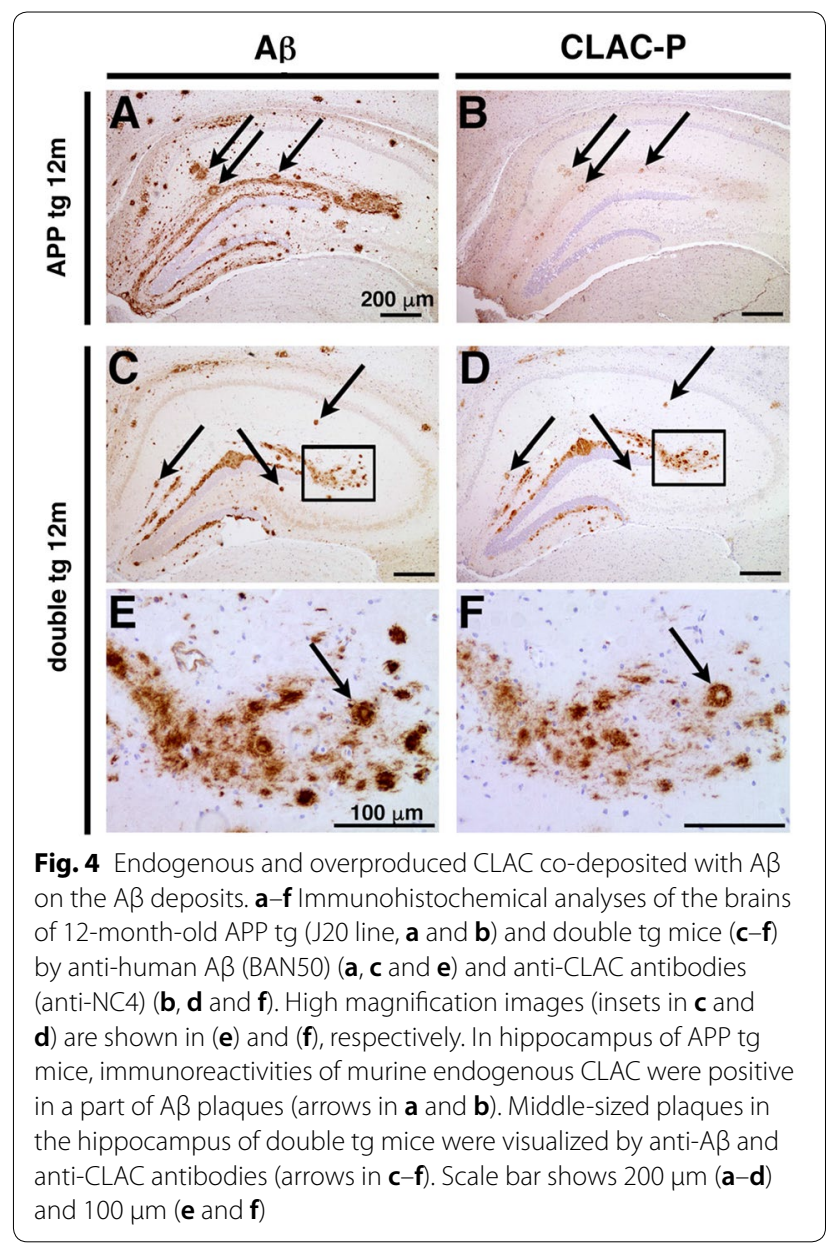

tg and 70.8 in double tg mice) and 3.45 times at $15 \mathrm{M}$ (38.2 in APP tg and 131.6 in double tg mice) compared with those in APP tg mice (Fig. 5c). We also examined the brains of 18-month-old APP tg (A7 line) and their littermate double tg mice with ThS and found that the average number of ThS-positive plaques in the piriform or frontal cortex of double tg mice also was significantly higher than those in APP tg mice (Fig. $5 \mathrm{f}-\mathrm{h}$ ). These data suggest that overexpression of CLAC-P promoted the compaction of $A \beta$ plaques in the brains of double tg mice.

To further examine whether CLAC remodels the morphology of pre-formed $A \beta$ plaques in the brains of APP tg mice, we have adopted the AAV9 model to overexpress human CLAC-P in the neurons of plaque-bearing APP tg mice. We generated AAV9 vector carrying dTomato-P2A-CLAC-P (AAV9-CLAC-P, Fig. 6a) under the human Synapsin I promoter, which bicistronically expresses both dTomato and human CLAC-P in neurons. AAV9-CLAC-P or PBS was stereotaxically injected into the hippocampus and neocortex of 14-month-old APP tg mice (A7 line) that already harbor A $\beta$ plaques both in the hippocampus and neocortex, to examine 

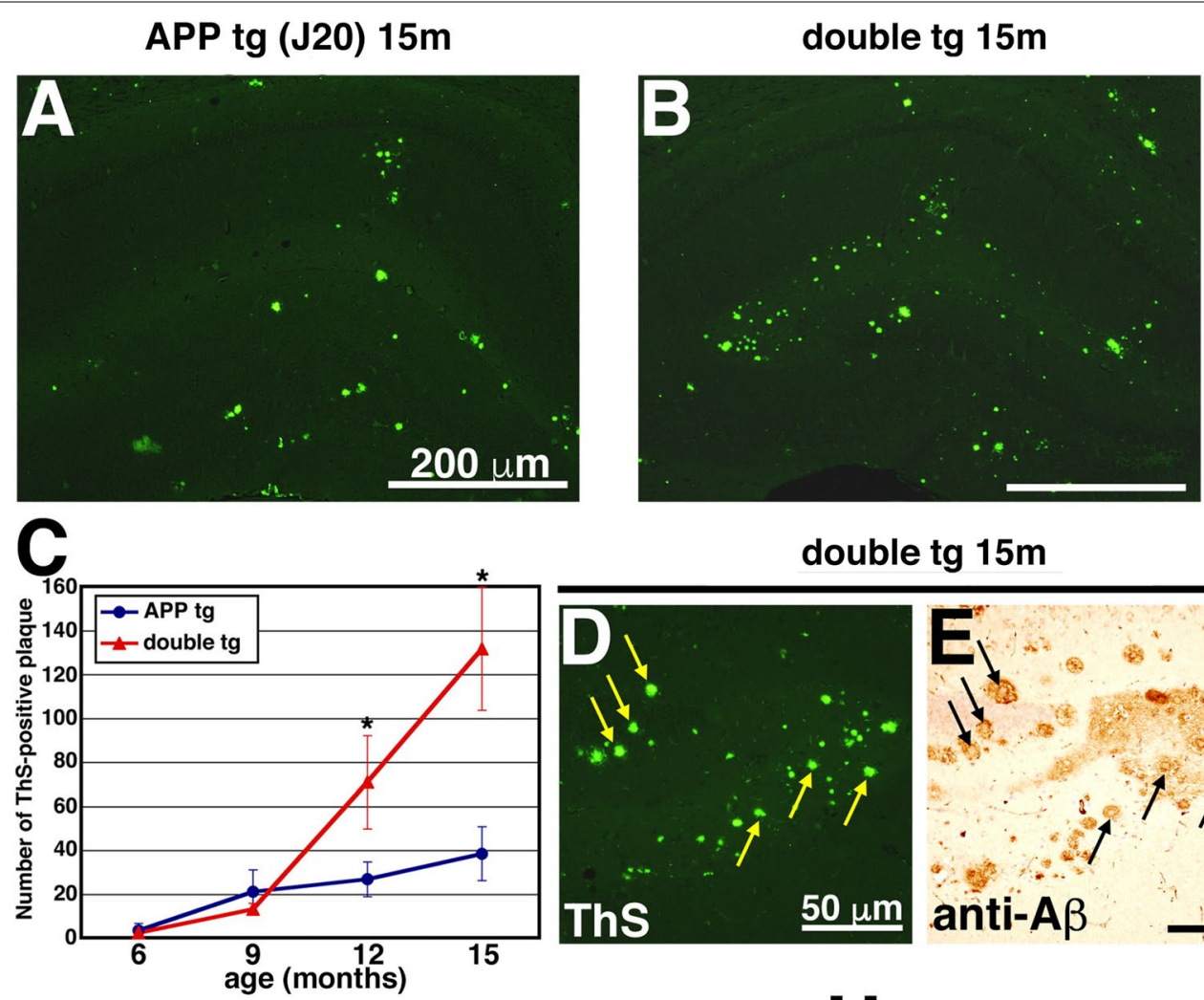

\section{double tg $15 \mathrm{~m}$}
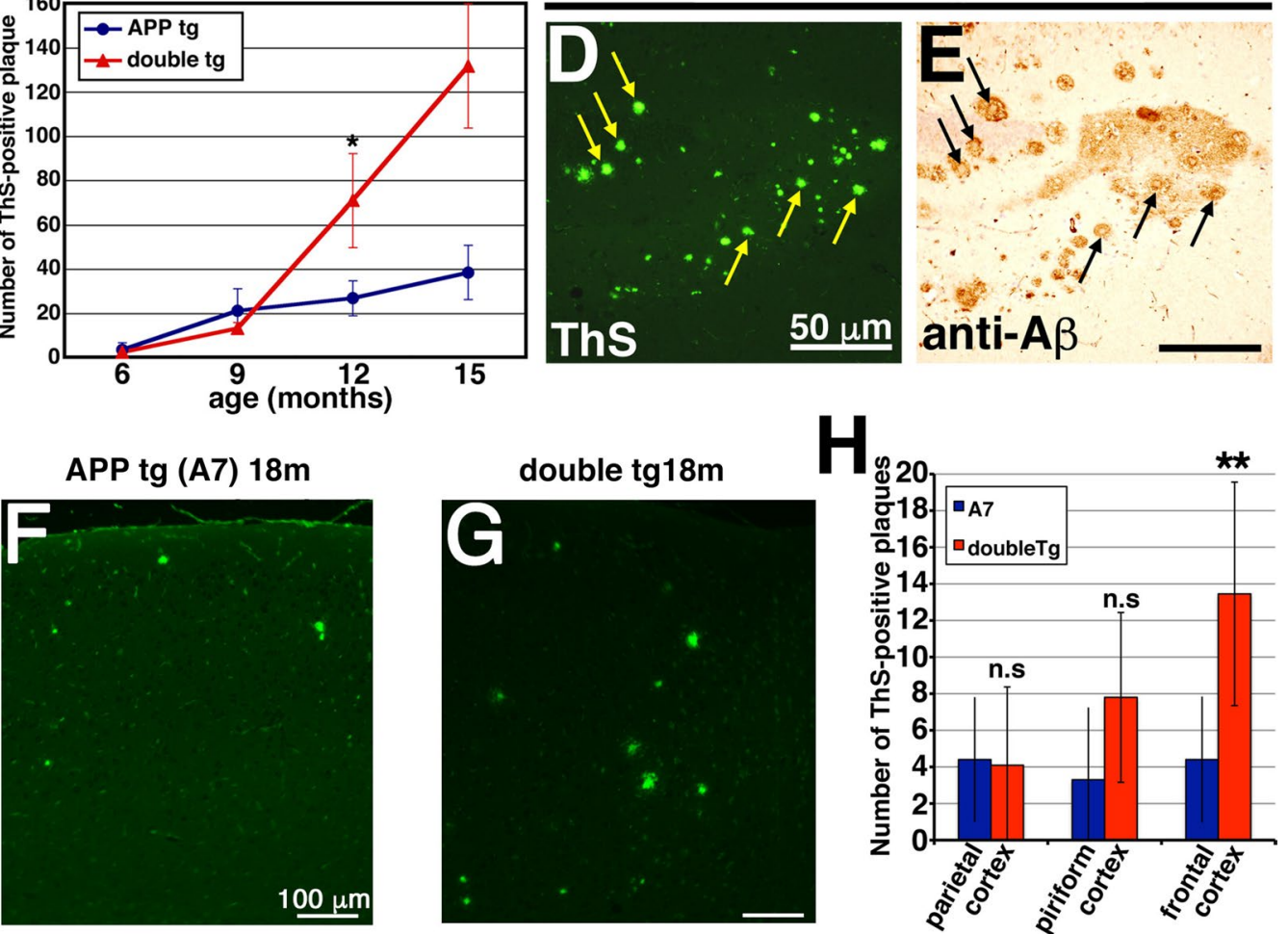

Fig. 5 Overexpression of CLAC-P significantly increased the number of ThS-positive plaques. $\mathbf{a}$, $\mathbf{b}$ ThS staining of the brains of 15-month-old APP tg (J20 line, a) and double tg mice (b). c The mean number of ThS-positive plaques was assessed in the hippocampus of 6-, 9-, 12-and 15-month-old APP tg mice (blue circles) and double tg mice (red triangles). $N=4,4,13,7$ for 6-, 9-, 12-, 15-month-old APP tg, respectively. $N=4,3,12,7$ for 6-, 9-, $12-, 15$-month-old double tg, respectively. Student's t-test, $p=0.81$ (6-month-old), $p=0.24$ (9-month-old), $p<0.0001$ (12-month-old), $p<0.0001$ (15-month-old). d e Serial sections stained with ThS (d) and anti-A $\beta$ antibody (BAN50) (e) were shown. The core-region of middle-sized plaques in the brains of 15-month-old double tg mice were exclusively labeled by ThS (arrows). $\mathbf{f}, \mathbf{g}$ ThS staining of the brains of 18-month-old APP tg (f) and double $\operatorname{tg}(\mathbf{g})$ mice. $\mathbf{h}$ The mean number of ThS-positive plaques assessed in the parietal, piriform and frontal cortices of APP tg and double tg mice. $N=4$, Student's t-test, $p=0.86$ (parietal cortex), 0.070 (piriform cortex), 0.00063 (frontal cortex), ${ }^{*}, p<0.01$. Scale bar shows $200 \mu \mathrm{m}(\mathbf{a}$ and $\mathbf{b}$ ), $50 \mu \mathrm{m}$ (d and $\mathbf{e}), 100 \mu \mathrm{m}(\mathbf{f}$ and $\mathbf{g})$

if expression of CLAC modifies the pre-existing $\mathrm{A} \beta$ plaques (Fig. 6b). Four months after injection, immunohistochemical analyses of the brains of APP tg mice showed dramatical changes of the morphology of $A \beta$ plaques in the ipsilateral hemispheres injected with
AAV9-CLAC-P: middle- or large- sized, well-circumscribed $A \beta$ plaques positive both for $A \beta$ and CLAC were seen, whereas amorphous diffuse-type $A \beta$ plaques disappeared (Fig. 6c), similarly to the observation in the brains of double tg mice (Figs. 2, 3). Notably, a larger number of 


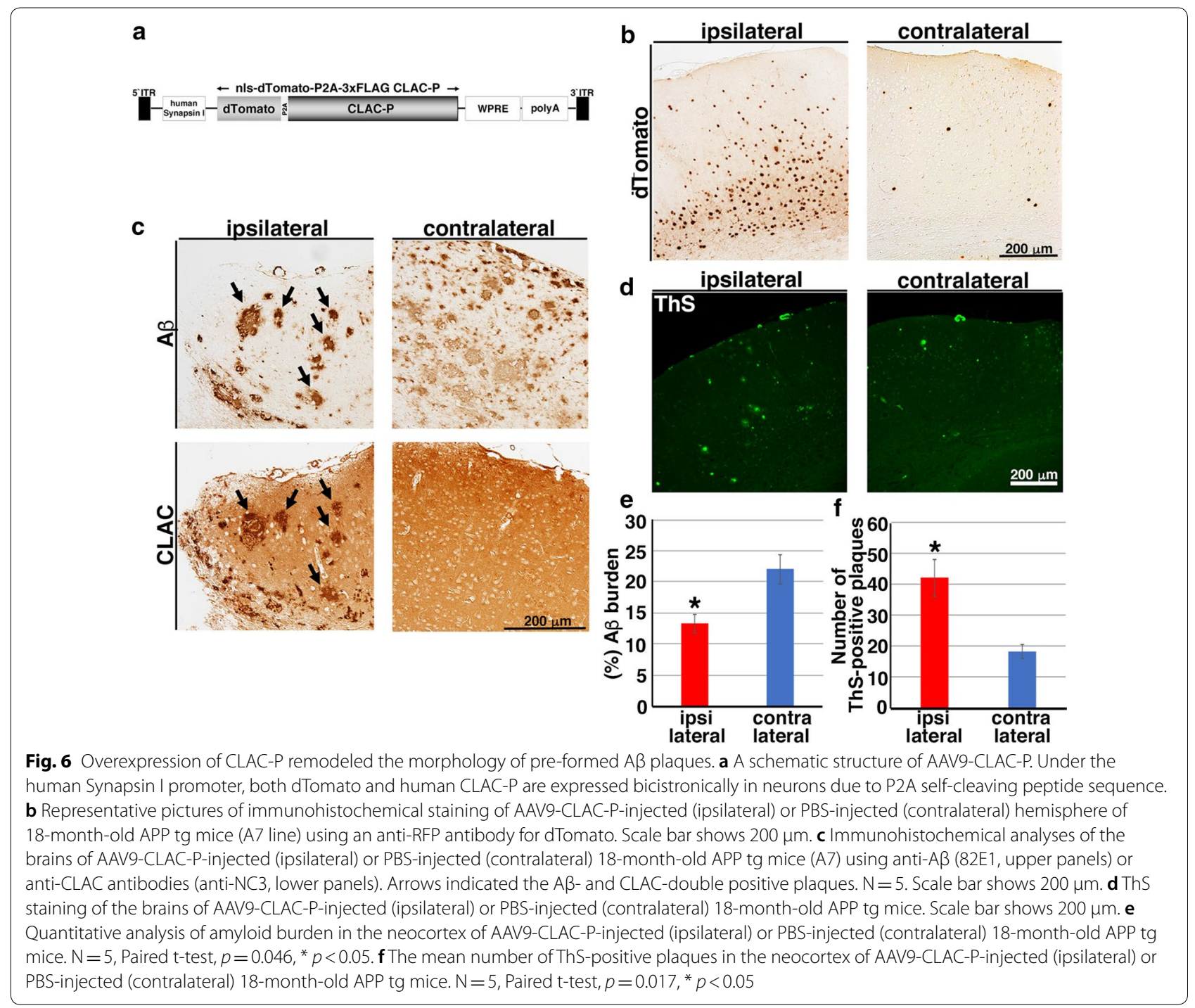

ThS-positive plaques were observed in the AAV9-CLACP-injected hemispheres compared with the PBS-injected side (Fig. 6d). Amyloid burden in the neocortices was significantly smaller in the neocortex ipsilateral to the injection side by $\sim 40 \%$ (mean values: $13.3 \%$ in ipsilateral and $22.0 \%$ in contralateral neocortex) (Fig. 6e). The average number of ThS-positive plaques in the ipsilateral neocortex was significantly higher by $\sim 2.3$ times compared to that in the contralateral neocortex (41.9 in ipsilateral and 18.2 in contralateral neocortex) (Fig. 6f). These data supported the hypothesis that CLAC remodels the morphology of $A \beta$ plaques into more compact and mature forms in the brain even after deposition.

Association of dystrophic neurites is a common feature of ThS-positive amyloid plaques in the brains of APP tg mice as well as of $\mathrm{AD}$ patients $[9,32]$. To examine the association of dystrophic neurites with $A \beta$ plaques in the brains of double tg mice, we immunostained serial sections from the brains of 15-month-old APP tg (J20 line) and their littermate double tg mice with an anti-A $\beta$ (82E1) and anti-ubiquitin antibodies, the latter being a marker for dystrophic neurites, and found that numerous ubiquitin-positive, swollen neurites were present in the periphery of A $\beta$ plaques in APP or double tg mice (Fig. 7). Notably, most of the middle-sized $A \beta$ plaques in the double tg mice were decorated with ubiquitin immunoreactivities (Fig. 7b, d); typically, the periphery of the amyloid core-positive, middle-sized $A \beta$ plaques were associated with numerous dystrophic neurites (Fig. 7e, f). The average number of ubiquitin-positive $A \beta$ plaques in hippocampus of double tg mice was significantly larger by $\sim 1.7$ times compared with those in APP tg mice (40 

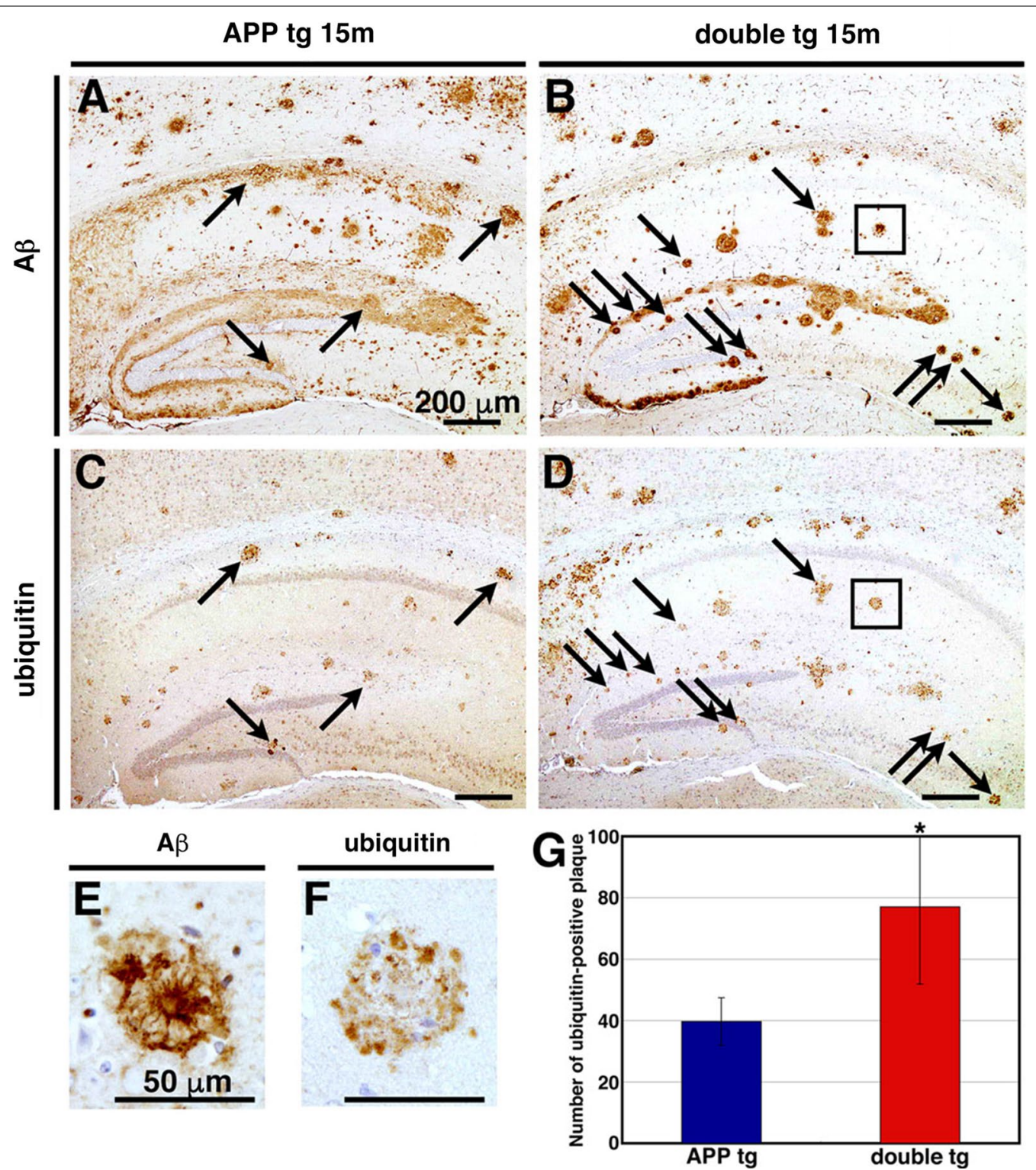

Fig. 7 Overexpression of CLAC-P significantly increased the number of ubiquitin-positive neuritic plaques. $\mathbf{a}-\mathbf{d}$ Immunohistochemical analyses of the brains of 15-month-old APP tg mice (J20 line, $\mathbf{a}$ and $\mathbf{c}$ ) and double tg mice (b and $\mathbf{d}$ ) using an anti-human A 3 antibody (BAN50) (a and $\mathbf{b})$ and an anti-ubiquitin antibody (c and $\mathbf{d}$ ). High magnification images (insets in $\mathbf{b}$ and $\mathbf{d}$ ) were shown in $\mathbf{e}$ and $\mathbf{f}$, respectively. A part of both $A \beta$ and ubiquitin positive plaques were highlighted (arrows). Scale bar shows $200 \mu \mathrm{m}(\mathbf{a}-\mathbf{d})$ and $50 \mu \mathrm{m}$ (e and $\mathbf{f})$. $\mathbf{g}$ The mean number of ubiquitin-positive plaques was assessed in the hippocampus of 15-month-old APP tg mice (blue, $\mathrm{N}=6$ ) and double tg mice (red, $\mathrm{N}=7$ ). Mann-Whitney $\mathrm{U}$ test, $p=0.0066$

A $\beta$ deposits/section in APP tg and 77 in double tg mice, Fig. 7g).

Association of reactive microglial cells also is a characteristic feature of mature $A \beta$ plaques [43]. To further examine the association of microglial cells in the brains of double tg mice, we immunolabelled serial sections from the brains of 15-month-old APP tg (J20 line) and their littermate double tg mice with an anti-A $\beta$ (BAN50) and anti-Ibal antibodies, the latter being a marker for microglial cells, and found the association of microglial cells at the periphery of $A \beta$ plaques in APP or double tg mice (Additional file 1: Supplementary Fig. 1A). Notably, middle-sized, well-circumscribed $A \beta$ plaques in the double tg mice were more densely associated with microglial 
cells than those in APP tg mice (Additional file 1: Supplementary Fig. 1A). The mean area of Iba1-immunoreactivities in hippocampus of $15 \mathrm{M}$ double tg mice (J20 line) was larger by $\sim 1.3$ times compared with that in APP $\operatorname{tg}$ mice $(4.06 \%$ in APP tg and $5.23 \%$ in double tg mice) (Additional file 1: Supplementary Fig. 1B), and that in the neocortex of $18 \mathrm{M}$ double tg mice (A7 line) was significantly larger by $\sim 6.8$ times compared with that in APP tg mice $(0.087 \%$ in APP tg and $0.59 \%$ in double tg mice) (Additional file 1: Supplementary Fig. 1C). These data suggest that overexpression of CLAC-P promoted the maturation of $\mathrm{A} \beta$ plaques, thereby increasing the plaqueassociated local toxicity represented by the increase in dystrophic neurites or the association of microglial cells.

\section{Decreased level of $A \beta$ in the brain interstitial fluid of double $\operatorname{tg}$ mice}

We next sought to examine whether the maturation of $A \beta$ plaques induced by association of CLAC affected the dynamics of soluble $A \beta$ in the brain parenchyma. To this end, we quantified the levels of $A \beta 42$ in the brain interstitial fluid (ISF) by in vivo microdialysis technique using a $1,000 \mathrm{kDa}$ molecular weight cut-off microprobe $[7,59]$, which represents soluble, diffusible, $<1000 \mathrm{kDa}$ $A \beta$ species present in the brain extracellular space. We also quantitated the levels of $A \beta 42$ extracted in TBS that corresponds to total soluble $A \beta$ in the brain. The levels of TBS-soluble $A \beta 42$ in the brain were similar between the 18-22-month-old APP tg (A7 line) and its littermate double tg mice (23.1 pM in APP tg and $18.9 \mathrm{pM}$ in double $\operatorname{tg}$ mice, Fig. 8a). On the scatterplot analysis, we found a positive correlation between the levels of TBS-soluble $A \beta 42$ and the percentage area of $A \beta$ burden in the APP tg mice, but not in the double tg mice $\left(R^{2}=0.322\right.$ in APP tg and $R^{2}=0.108$ in double tg mice, Fig. 8b). In sharp contrast, we found that the levels of ISF A $\beta 42$ in the hippocampus of 18-22-month-old double tg mice were significantly lower than that of APP tg mice $(16.5 \mathrm{pM}$ in APP $\operatorname{tg}$ and $11.6 \mathrm{pM}$ in double tg mice, Fig. 8c). We also found a negative correlation between ISF $A \beta 42$ and the percentage area of $A \beta$ burden in the APP tg mice, but not in the double tg mice $\left(R^{2}=0.385\right.$ in APP tg and $R^{2}=0.042$ in double tg mice, Fig. $8 \mathrm{~d}$ ). These results suggest that ISF $A \beta$ may be captured by $A \beta$ deposits and sequestered from ISF, and consequently, CLAC-positive, more compact $A \beta$ plaques in the brains of double tg mice might have sequestered soluble $A \beta$ from the ISF to a greater extent compared with that in APP tg mice. To verify this idea, we quantified the levels of TBS-soluble brain A $\beta 42$ and ISF A 342 in 5-7-month-old APP tg mice and its littermate double tg mice that have not developed plaques yet. Comparable levels of TBS-soluble brain A $\beta 42$ and ISF A $\beta 42$ in the hippocampus were detected between APP tg and double tg mice (Fig. 8e, f). Taken together, we concluded that CLAC might be one of the determinants of the morphology of $A \beta$ plaques, which promotes the compaction of $A \beta$ deposits, thereby altering the dynamics of soluble $A \beta$ in the brain.

\section{CLAC impacts the compaction of $A \beta$ plaques without influencing the total amount of insoluble $A \beta$} To ask whether CLAC influenced the levels of insoluble $A \beta$ in vivo, we quantified $A \beta 40$ and $A \beta 42$ in the formic acid extracts of the SDS-insoluble fraction from the brains of 6, 9, 12 or 15-month-old wild type, CLAC-P tg, APP $\operatorname{tg}$ (J20 line) or littermate double tg mice by ELISAs. The levels of SDS-insoluble, formic-acid soluble human $A \beta 40$ and $A \beta 42$ in the brains of APP tg mice started to increase at ages of 9 and 6 months, respectively (Fig. 9). No significant differences in the levels of SDS-insoluble, formic-acid soluble $A \beta 40$ or $A \beta 42$ in the brains were found between APP and double tg mice. We also found that the levels of SDS-insoluble, formic-acid soluble A $\beta 40$ and A 342 in the brains of 18-month-old APP tg (A7 line) and littermate double tg mice (data not shown) also were similar. These data suggested that CLAC did not affect the total amount of insoluble $A \beta$ in the brain.

Lastly, we asked whether co-deposition of CLAC on the $A \beta$ plaques influences the pattern of distribution in $A \beta$ deposition. A number of CLAC-positive small deposits were observed in the neocortices of CLAC-P tg (Fig. 1e) or double tg (J20 line, Additional file 1: Supplementary Fig. 2B, D) mice. Ultrastructural analysis showed that extracellular filamentous aggregates positively labeled by an anti-CLAC-P antibody (NC4) were present in the cortex of double tg mouse (Additional file 1: Supplementary Fig. 2E). We confirmed that these CLAC-positive deposits were entirely $A \beta$-negative (Additional file 1: Supplementary Fig. 2). This may suggest that CLAC aggregates do not directly interact with secreted non-fibrillar $A \beta$ and elicit deposition of $A \beta$ fibrils.

\section{Discussion}

To examine the roles of CLAC as an A $\beta$-plaque associated protein in the plaque formation and $A \beta$ dynamics in brains, we have generated tg mice that doubly overexpress human CLAC-P and APP, and observed a dramatic increase in compact plaques with ThS-positive cores, a decrease in diffuse plaques, and a significant decrease in the ISF $A \beta$ levels in the double tg compared with the APP single tg mice. In contrast, the levels of SDS-insoluble, formic acid-soluble $A \beta$, as well as those of TBS-soluble $A \beta$, were comparable between the single and double tg mice. Based on these data, we speculated that CLAC impacted on the process of amyloid plaque formation, specifically by promoting the compaction of $A \beta$ deposits, 
a

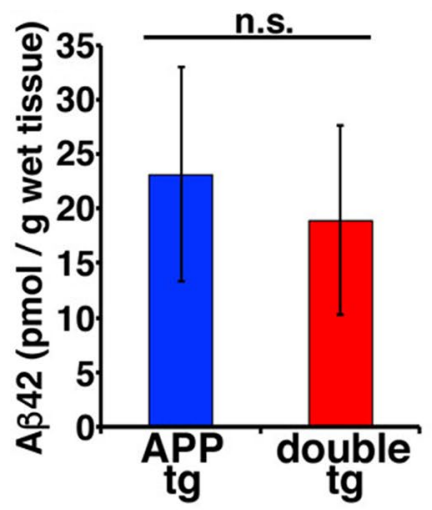

C
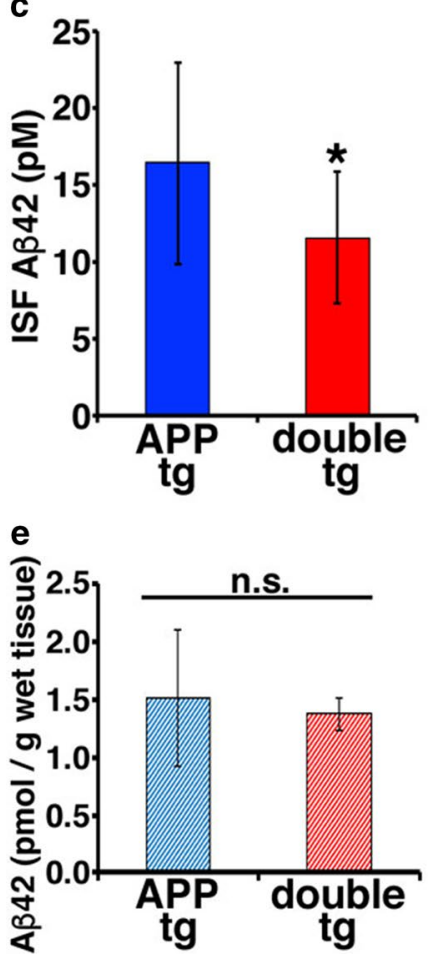

b
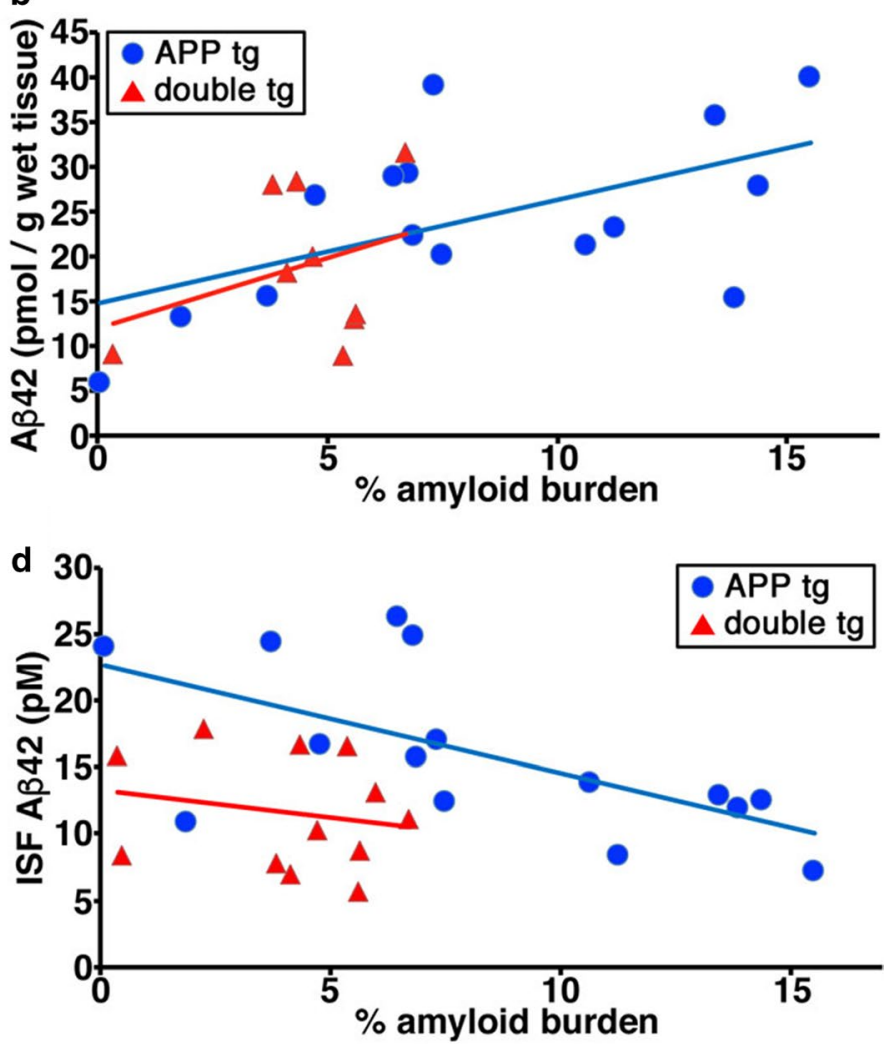

f

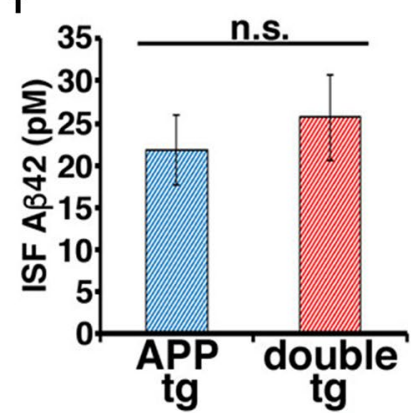

Fig. 8 ISF A $\beta$ in the brain of double tg was significantly decreased compared with APP tg. a The concentration of A 42 (pmol/g wet tissue) in the TBS-soluble fraction of the brains of 18-19-month-old APP $\operatorname{tg}$ (A7 line) and double tg mice. $N=13$ (APP $\operatorname{tg}$ ), and 9 (double tg). The mean \pm SD Student's t-test, $p=0.31$ n.s. means no significant difference. $\mathbf{b}$ Correlation between the concentration of TBS-soluble A 342 and area of A $\beta$ deposits in hippocamps of the brains of 18-22-month-old APP and double tg mice. $R^{2}=0.322$ (APP $\operatorname{tg}$ ), $R^{2}=0.108$ (double tg). $\mathbf{c}$ The concentration of A 42 (pM) in brain ISF of 18-19-month-old APP and double tg mice. $N=13$ (APP tg), and 12 (double tg). The mean \pm SD Student's t-test, $p=0.040$. d Correlation between the concentration of ISF A 42 and area of A $\beta$ deposits in hippocamps of the brains of 18-22-month-old APP and double $\operatorname{tg}$ mice. $R^{2}=0.385$ (APP tg), $R^{2}=0.0416$ (double tg). e The concentration of A 342 (pmol/g wet tissue) in the TBS-soluble fraction of the brains of 5-7-month-old APP and double tg mice. $N=4$ (APP tg), and 4 (double tg). The mean \pm SD Welch's t-test, $p=0.67$. n.s. means no significant difference. $\mathbf{f}$ The concentration of ISF A 42 (pM) in the brains of 5-7-month-old APP and double tg mice. $N=4$ (APP tg), and 4 (double tg). The mean \pm SD Student's t-test, $p=0.28$. n.s. means no significant difference

leading to the maturation of $A \beta$ plaques as well as an alteration in the dynamics of $A \beta$ in the interstitial fluids.

Although we found that the disappearance of diffuse type $A \beta$ plaques and an increase in the number of compact $\mathrm{A} \beta$ plaques with ThS-positive amyloid cores in the brains of double tg mice and AAV9-CLAC-P-infected APP tg mice, it is unclear how CLAC alters the morphology of $A \beta$ plaques in the brain. One possible mechanism 


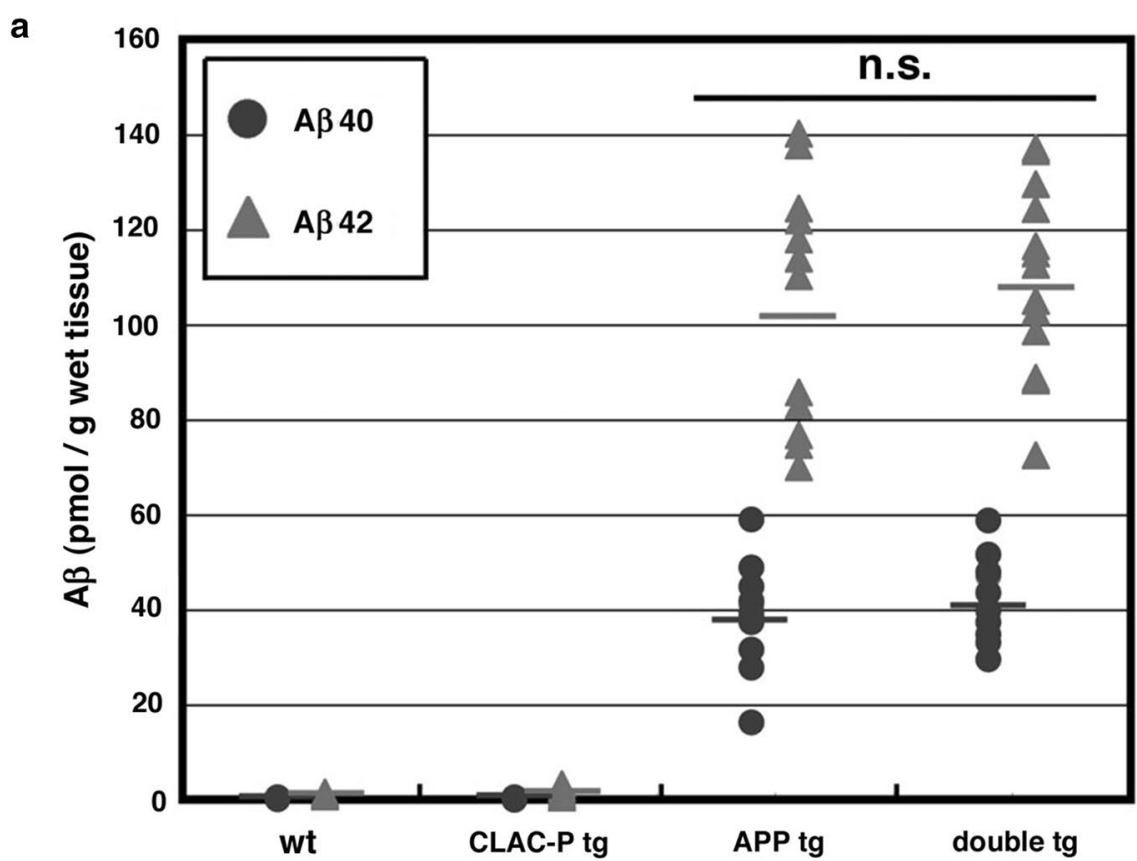

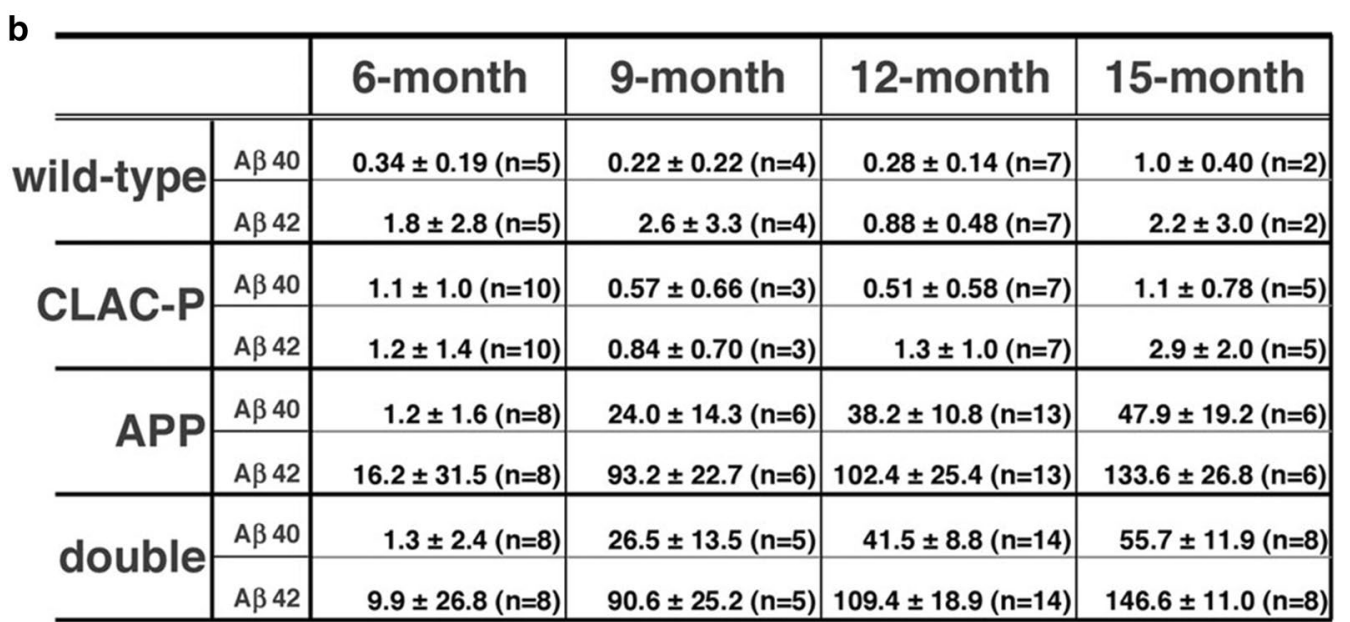

(pmol / g wet tissue \pm S. D.) (number)

Fig. 9 Similar levels of insoluble A in the brains of APP and double tg mice. a The concentration of A 340 (circles) and A 342 (triangles) in the $2 \%$ SDS-insoluble, 70\% formic acid-soluble fraction of the brains of 12-month-old wild-type ( $N=7), C L A C-P \operatorname{tg}(N=7), A P P \operatorname{tg}(J 20$ line, $N=13)$ and double $\operatorname{tg}(N=14)$ mice were measured by a two-site ELISA. Student's t-test, $p=0.40$ (A $\beta 40$ in APP tg vs A 340 in double tg), 0.44 (Aß42 in APP tg vs $A \beta 42$ in double tg). n.s. means no significant difference. $\mathbf{b}$ The levels of $A \beta 40$ and $A \beta 42$ in the SDS-insoluble, $70 \%$ formic acid-soluble fraction of the brains of 6-, 9-, 12- and 15-month-old double tg mice and littermates. The mean \pm SD of the amount of A 440 and A 42 are shown

would be that CLAC pre-existed within plaques further attracted $A \beta$ fibrils onto the plaques, resulting in an increase in the density of $\mathrm{A} \beta$ fibrils and compaction of amyloid plaques. Our previous findings that CLAC specifically interacted with fibrillized form of $A \beta[18$, 37], and that CLAC was exclusively positive on amyloid bundles in the primitive or typical SPs in AD brains, but not on the diffuse type SPs [27], may support this view. However, we have observed a number of CLAC-positive small deposits within the entire neocortices of CLAC-P $\operatorname{tg}$ or double tg mice that were entirely negative for $A \beta$; the finding that CLAC aggregates per se do not directly elicit $A \beta$ deposition in the brain parenchyma may imply that CLAC/A $\beta$ co-deposits that harbor a specific 
conformation that attracts $\mathrm{A} \beta$ fibrils might be involved in the amyloid compaction.

Another possible scenario would be that CLAC deposited with $A \beta$ in the periphery of plaques drives the deposition of $A \beta$ fibrils concentrically into amyloid plaques, leading them to closely pack at the center of amyloid plaques. In this context, it is noteworthy that the binding of CLAC has been suggested to confer protease resistance to amyloid fibrils [44]. It is tempting to speculate that CLAC associated with $\mathrm{A} \beta$ plaques affects the microglial phagocytosis or proteolysis of amyloid fibrils, resulting in the remodeling and compaction of $\mathrm{A} \beta$ plaques.

We have shown that overexpression of CLAC-P impacts on the compaction of $A \beta$ plaques in the brain, although the levels of CLAC polypeptides in the brain required for the compaction of $A \beta$ plaques remained to be estimated. To address this question, further biochemical and histochemical studies using APP tg mice injected with various concentrations of AAV9-CLAC-P may be required. It may also be critical to investigate whether the deficiency in murine CLAC-P gene decreases the maturation of $A \beta$ plaques in the brains of APP tg mice. We have previously reported that CLAC-P deficient mice exhibited perinatal lethality due to the incomplete formation of neuromuscular junctions [50]. Cross of APP tg mice with adult neuron-specific conditional CLAC-P knockout mice will provide us with an answer to the question.

It also remains an open question whether the co-deposition of CLAC on SPs together with $A \beta$ acts deteriorative or protective in the pathophysiology of AD. We found a significant increase in the number of ThS-positive plaques, ubiquitin-positive dystrophic neurites and microglial cells in the brains of double tg mice compared with the APP single tg. It has been speculated that ThSpositive plaques are associated with local neurotoxicity [52] or affect the neurite trajectories and synaptic structures compared with ThS-negative $A \beta$ plaques in the brains of patients with AD and APP tg mice $[5,9,32]$. These results prompted us to speculate if the brains of double tg mice may suffer from higher vulnerability to neurodegeneration compared with APP tg mice. Altogether, CLAC may play an important role in the remodeling of $A \beta$ plaques into matured plaques in relation to the pathogenesis of AD. Further behavioral studies and more quantitative analysis of neurons and synapses in tg brains may provide us with further clues to the significance of CLAC in amyloid plaques.

In the brain of APP tg mice, we found a positive correlation between the levels of TBS-soluble $A \beta 42$ and the area of $A \beta$ burden, whereas the levels of ISF $A \beta 42$ and the areas of $A \beta$ burden were negatively correlated. These apparently contradictory results led us to hypothesize that SPs might have dual functions against soluble $A \beta$ as a sink and a reservoir in the brain: SPs may sequester soluble $A \beta$ from ISF and retain $A \beta$ on the surface of the plaques. Thus, the levels of ISF $A \beta$ are decreased and those of TBS-soluble $A \beta$ increased, as $A \beta$ accumulates on plaques in the brain. In accordance with the classical observation that soluble radiolabeled $A \beta(1-40)$ is accumulated on SPs in frozen tissue sections from AD brains in vitro [30], it has been shown that exogenous administration of soluble radiolabeled $A \beta(1-40)$ into the brains significantly lowers the recovery rate of $A \beta$ in the ISF of plaque-rich APP tg mice compared with that in plaquefree mice [21]. In vivo stable isotope-labeling kinetics studies in $A D$ patients showed that the presence of amyloid plaques led to a dramatic slowing of $A \beta$ turnover $[38,39]$. Taken together with our present data, one could argue that the amyloid plaques act as a reversible exchange pool of soluble $A \beta$ in the brain, which impacts on the dynamics of soluble $A \beta$. We have observed a significantly lower ISF level of $A \beta$ in the brains of plaquerich double tg mice compared with APP single tg mice, although the levels of $A \beta$ recovered in the TBS-soluble fraction were similar. In contrast, the levels of ISF $A \beta$ in the brains of plaque-free double tg mice was comparable to those in APP tg mice. These data suggest that the maturation of $A \beta$ plaques, which was caused by overexpression of CLAC-P in the double tg mice in the present study, might have promoted the sequestration of soluble $A \beta$ from ISF onto the $A \beta$ plaques. This also supports our speculation that the morphology of amyloid plaques, along with the amount of amyloid deposition, is a determinant of the dynamics of soluble $A \beta$ in the brain extracellular milieu.

A number of non- $\mathrm{A} \beta$ protein components have been identified in SPs other than CLAC [11]. Apolipoprotein $\mathrm{E}$ (apoE), whose polymorphism has been identified as a major genetic risk factor for $\mathrm{AD}[8,40,46]$, is codeposited with $\mathrm{A} \beta$ in $\mathrm{AD}$ brains [36]. Ablation of $A P O E$ gene in the APP tg mice caused a dramatic decrease in the number of Congo red or ThS-positive fibrillar $A \beta$ deposits $[3,4,49]$, and an increase in the diffuse-type $\mathrm{A} \beta$ deposits $[19,20,53]$. It is noteworthy that the levels of ISF $A \beta$ as well as cerebrospinal fluid $A \beta$ in the brains of plaque-free $A P O E-/-$ APP tg mice was significantly increased compared with those of APP tg mice [10]. It seems likely that apoE influences the dynamics of soluble $A \beta$ and facilitates the conversion of soluble $A \beta$ into forms with a high $\beta$-sheet content. We found no changes in the level of ISF A $\beta$ in the brains of plaque-free APP/ CLAC-P double tg mice compared with the APP single tg 
mice. This suggests that CLAC affects the morphology of $A \beta$ plaques and the brain dynamics of soluble $A \beta$ in a different manner from that of apoE.

In sum, we have shown that the association of CLAC contributes to the maturation of $A \beta$ plaques in the brain, which may mediate the local toxicity around the deposits and impact the dynamics of soluble $A \beta$, using a mouse model of AD overexpressing CLAC-P and APP. These findings will give us clues as to the origin of different forms of $A \beta$ plaques in $A D$ brains, and further provide a novel therapeutic target for AD through suppression of SP maturation, for example, by inhibiting the interaction between CLAC and A $\beta$ fibrils.

\section{Conclusion}

We reveal that CLAC remodels $A \beta$ plaques into more compact and mature forms, and reduces the soluble $A \beta$ species in the interstitial fluid in the brains of APP transgenic mice. CLAC acts as a molecular determinant of the $A \beta$ plaque morphology, which consequently alters the dynamics of $A \beta$ presumably by sequestering the soluble A $\beta$ from brain extracellular space to plaques.

\section{Supplementary information}

Supplementary information accompanies this paper at https://doi. org/10.1186/s40478-020-01075-5.

Additional file 1. Supplementary methods. Supplementary Fig. 1: Immunohistochemical analyses using an antibody to microglia; Supplementary Fig. 2: Immunnohistochemical analyses and ultrastructure of CLACpositive cortical deposits.

\section{Abbreviations}

AAV9: Adeno-associated virus serotype 9; aCSF: Artificial cerebrospinal fluid; AD: Alzheimer's disease; $A \beta$ : Amyloid- $\beta$ peptide; APP: $A \beta$ precursor protein; CLAC: Collagenous Alzheimer amyloid plaque component; CLAC-P: CLAC precursor protein; COL25A1: Collagen type XXV a1 chain; DMSO: Dimethyl sulfoxide; ELISA: Enzyme-linked immunosorbent assay; ISF: Interstitial fluid; PBS: Phosphate-buffered saline; SP: Senile plaque; TBS: Tris-buffered saline; tg: Transgenic; ThS: Thioflavin S.

\section{Acknowledgements}

We thank Dr. Hisatomo Kowa and Ms. Tomoko Sakakura for technical support and valuable comments, Novartis Pharma for Thy 1.2 expression cassette, and Takeda Pharmaceutical Company Limited for anti-A $\beta$ monoclonal antibodies.

\section{Authors' contributions}

TH, TW, and TI designed the experiments. TH, DF, YN, MHK, YM, YM, TS and HK performed the experiments. TH and TI analyzed the data. TH and TI wrote the manuscript. TH, TW, and TI acquired the funding.

\section{Funding}

This work is supported by a Grants-in-Aid for Scientific Research (B) (T.I. 17H04193), a Grants-in-Aid for Scientific Research (A) (T.I. 20H00525), a Grant from Grants-in-Aid for Young Scientists (B) (T.H. 19790050), by a Grant-in-Aid for Research Activity Start-up (T.H. 24800015) from the Japan Society for the Promotion of Science Japan, grant from the Takeda Science Foundation (T.H.), and a research grant from the Mochida Memorial Foundation (T.H.).

\section{Availability of data and materials}

The datasets and materials used and/or analyzed during the current study are available from the corresponding author on reasonable request.

\section{Ethics approval}

The animal care and use procedures were approved by the Institutional Animal Care and Use Committees of the University of Tokyo (08-P-090, 13-P-112, 18-P-108)

\section{Competing interests}

The authors declare that they have no competing interest.

\section{Author details}

${ }^{1}$ Department of Neuropathology, Graduate School of Medicine, The University of Tokyo, 7-3-1 Hongo, Bunkyo-ku, Tokyo 113-0033, Japan. ${ }^{2}$ Department of Innovative Dementia Prevention, Graduate School of Medicine, The University of Tokyo, 7-3-1 Hongo, Bunkyo-ku, Tokyo 113-0033, Japan. ${ }^{3}$ Department of Neuropathology and Neuroscience, Graduate School of Pharmaceutical Sciences, The University of Tokyo, 7-3-1 Hongo, Bunkyo-ku, Tokyo 113-0033, Japan.

Received: 23 June 2020 Accepted: 11 November 2020

Published online: 07 December 2020

\section{References}

1. Asami-Odaka A, Ishibashi Y, Kikuchi T, Kitada C, Suzuki N (1995) Long amyloid $\beta$-protein secreted from wild-type human neuroblastoma IMR32 cells. Biochem 34:10272-10278

2. Bai B, Hales CM, Chen PC, Gozal Y, Dammer EB, Fritz JJ et al (2013) U1 small nuclear ribonucleoprotein complex and RNA splicing alterations in Alzheimer's disease. Proc Natl Acad Sci USA 110:16562-16567

3. Bales KR, Verina T, Dodel RC, Du Y, Altstiel L, Bender M et al (1997) Lack of apolipoprotein E dramatically reduces amyloid $\beta$-peptide deposition. Nat Genet 17:263-264

4. Bales KR, Verina T, Cummins DJ, Dodel RC, Saura J, Fishman CE et al (1999) Apolipoprotein $E$ is essential for amyloid deposition in the APPV717F transgenic mouse model of Alzheimer's disease. Proc Natl Acad Sci USA 96:15233-15238

5. Brenda RP, O'Brien C, Simmons K, McKeel DW, Bales KR, Paul SM et al (2003) PDAPP; YFP double transgenic mice: a tool to study amyloid- $\beta$ associated changes in axonal, dendritic, and synaptic structures. J Comp Neurol 456:375-383

6. Citron M, Oltersdorf T, Haass C, McConlogue L, Hung AY, Seubert P et al (1992) Mutation of the $\beta$-amyloid precursor protein in familial Alzheimer's disease increases $\beta$-protein production. Nature 360:672-674

7. Cirrito JR, May PC, O'Dell MA, Taylor JW, Parsadanian M, Cramer JW et al (2003) In vivo assessment of brain interstitial fluid with microdialysis reveals plaque-associated changes in amyloid- $\beta$ metabolism and half-life. J Neurosci 23:8844-8853

8. Corder EH, Saunders AM, Strittmatter WJ, Gaskell PC, Small GW, Roses AD et al (1993) Gene dose of apolipoprotein E type 4 allele and the risk of Alzheimer's disease in late onset families. Science 261:921-923

9. D'Amore JD, Kajdasz ST, McLellan ME, Bacskai BJ, Stern EA, Hyman BT (2003) In vivo multiphoton imaging of a transgenic mouse model of Alzheimer disease reveals marked thioflavine-S-associated alterations in neurite trajectories. J Neuropathol Exp Neurol 62:137-145

10. DeMattos RB, Cirrito JR, Parsadanian M, May PC, O'Dell MA, Taylor JW et al (2004) ApoE and clusterin cooperatively suppress levels and deposition: evidence that apoE regulates extracellular $A \beta$ metabolism in vivo. Neuron 41:193-202

11. Dickson DW (1997) The pathogenesis of senile plaques. J Neurochem Exp Neurol 56:321-339

12. Duyckaerts C, Delatour B, Potier MC (2009) Classification and basic pathology of Alzheimer disease. Acta Neuropathol 118:5-36

13. Erikson GA, Bodian DL, Rueda M, Molparia B, Scott ER, Scott-Van Zeeland AA et al (2016) Whole-genome sequencing of a healthy aging cohort. Cell 165:1002-1011 
14. Forsell C, Björk BF, Lilius L, Axelman K, Fabre SF, Fratiglioni L et al (2010) Genetic association to the amyloid plaque associated protein gene COL25A1 in Alzheimer's disease. Neurobiol Aging 31:409-415

15. Games D, Adams D, Alessandrini R, Barbour R, Berthelette P, Blackwell C, Carr T, Clemens J, Donaldson T, Gillespie F et al (1995) Alzheimer-type neuropathology in transgenic mice overexpressing V717F $\beta$-amyloid precursor protein. Nature 373:523-527

16. Goate A, Chartier-Harlin MC, Mullan M, Brown J, Crawford F, Fidani L et al (1991) Segregation of a missense mutation in the amyloid precursor protein gene with familial Alzheimer's disease. Nature 349:704-706

17. Glenner GG, Wong CW (1984) Alzheimer's disease: initial report of the purification and characterization of a novel cerebrovascular amyloid protein. Biochem Biophys Res Commun 120:885-890

18. Hashimoto T, Wakabayashi T, Watanabe A, Kowa H, Hosoda R, Nakamura A et al (2002) CLAC: a novel Alzheimer amyloid plaque component derived from a transmembrane precursor, CLAC-P/collagen type XXV. EMBO J 21:1524-1534

19. Holtzman DM, Bales KR, Tenkova T, Fagan AM, Parsadanian M, Sartorius $L J$ et al (2000) Apolipoprotein E isoform-dependent amyloid deposition and neuritic degeneration in a mouse model of Alzheimer's disease. Proc Natl Acad Sci USA 97:2892-2897

20. Holtzman DM (2004) In vivo effects of ApoE and clusterin on amyloid- $\beta$ metabolism and neuropathology. J Mol Neurosci 23:247-254

21. Hong S, Quintero-Monzon O, Ostaszewski BL, Podlisny DR, Cavanaugh WT, Yang T et al (2011) Dynamic analysis of amyloid $\beta$-protein in behaving mice reveals opposing changes in ISF versus parenchymal $A \beta$ during age-related plaque formation. J Neurosci 31:15861-15869

22. Hori Y, Hashimoto T, Nomoto H, Hyman BT, Iwatsubo T (2015) Role of Apolipoprotein $E$ in $\beta$-amyloidosis: isoform-specific effects on protofibril to fibril conversion of $A \beta$ in vitro and brain $A \beta$ deposition in vivo. J Biol Chem 290:15163-15174

23. Hsiao K, Chapman P, Nilsen S, Eckman C, Harigaya Y, Younkin S et al (1996) Correlative memory deficits, A $\beta$ elevation, and amyloid plaques in transgenic mice. Science 274:99-103

24. Iwatsubo T, Odaka A, Suzuki N, Mizusawa H, Nukina N, Ihara Y (1994) Visualization of $A \beta 42(43)$ and $A \beta 40$ in senile plaques with end-specific $A \beta$ monoclonals: evidence that an initially deposited species is $A \beta 42(43)$. Neuron 13:45-53

25. Iwatsubo T, Mann DMA, Odaka A, Suzuki N, Ihara Y (1995) Amyloid $\beta$ protein (A $\beta$ ) deposition: a $\beta 42(43)$ precedes $A \beta 40$ in Down syndrome. Ann Neurol 37:294-299

26. Iwatsubo T (1999) Amyloid deposits and plaque formation. In: Clark CM, Trojanowski JQ (eds) Neurodegenerative dementias. McGraw-Hill Professional, London, pp 147-150

27. Kowa H, Sakakura T, Matsuura Y, Wakabayashi T, Mann DMA, Duff K et al (2004) Mostly separate distributions of CLAC-versus AB40- or thioflavin $S$-reactivities in senile plaques reveal two distinct subpopulations of $\beta$-amyloid deposits. Am J Pathol 165:273-281

28. Liao L, Cheng D, Wang J, Duong DM, LosikTG, Gearing M et al (2004) Proteomic characterization of postmortem amyloid plaques isolated by laser capture microdissection. J Biol Chem 278:37061-37068

29. Lutz BM, Peng J (2018) Deep profiling of the aggregated proteome in Alzheimer's disease: from pathology to disease mechanisms. Proteomes 6:E46

30. Maggio JE, Stimson ER, Ghilardi JR, Allen CJ, Dahl CE, Whitcomb DC et al (1992) Reversible in vitro growth of Alzheimer disease $\beta$-amyloid plaques by deposition of labeled amyloid peptide. Proc Natl Acad Sci USA 89:5462-5466

31. Masliah E, Terry RD, Mallory M, Alford M, Hansen LA (1990) Diffuse plaques do not accentuate synapse loss in Alzheimer's disease. Am J Pathol 137:1293-1297

32. Masliah E, Sisk A, Mallory M, Mucke L, Schenk D, Games D (1996) Comparison of neurodegenerative pathology in transgenic mice overexpressing V717F $\beta$-amyloid precursor protein and Alzheimer's disease. J Neurosci 16:5795-5811

33. Mucke L, Masliah E, Yu GQ, Mallory M, Rockenstein EM, Tatsuno G et al (2000) High-level neuronal expression of $A \beta_{1-42}$ in wild type human amyloid protein precursor transgenic mice: synaptotoxicity without plaque formation. J Neurosci 20:4050-4058

34. Mullan M, Crawford F, Axelman K, Houlden H, Lilius L, Winblad B et al (1992) A pathogenic mutation for probable Alzheimer's disease in the APP gene at the N-terminus of $\beta$-amyloid. Nat Genet 1:345-347

35. Munezane H, Oizumi H, Wakabayashi T, Nishio S, Hirasawa T, Sato T et al (2019) Roles of collagen XXV and its putative receptors PTP $\sigma / \delta$ in intramuscular motor innervation and congenital cranial dysinnervation disorder. Cell Rep 29:4362-4376

36. Namba Y, Tomonaga M, Kawasaki H, Otomo E, Ikeda K (1991) Apolipoprotein $\mathrm{E}$ immunoreactivity in cerebral amyloid deposits and neurofibrillary tangles in Alzheimer's disease and kuru plaque amyloid in CerutzfeldtJakob disease. Brain Res 541:163-166

37. Osada Y, Hashimoto T, Nishimura A, Matsuo Y, Wakabayashi T, Iwatsubo T (2005) CLAC binds to amyloid $\beta$ peptides through the positively charged amino acid cluster within the collagenous domain 1 and inhibits formation of amyloid fibrils. J Biol Chem 280:8596-8605

38. Patterson BW, Elbert DL, Mawuenyega KG, Kasten T, Ovod V, Ma S et al (2015) Age and amyloid effects on human central nervous system amyloid-beta kinetics. Ann Neurol 78:439-453

39. Potter R, Patterson BW, Elbert DL, Ovod V, Kasten T, Sigurdson W et al (2013) Increased in vivo amyloid- $\beta 42$ production, exchange, and loss in presenilin mutation carriers. Sci Transl Med 5:189ra77

40. Reiman EM, Arboleda-Velasquez JF, Quiroz YT, Huentelman MJ, Beach TG, Caselli RJ et al (2020) Exceptional low likelihood of Alzheimer's dementia in APOE2 homozygotes from a 5,000-person neuropathological study. Nat Commun 11:667

41. Selkoe DJ, Hardy J (2016) The amyloid hypothesis of Alzheimer's disease at 25 years. EMBO Mol Med 8:595-608

42. Serrano-Pozo A, Frosch MP, Masliah E, Hyman BT (2011) Neuropathological alterations in Alzheimer disease. Cold Spring Harb Perspect Med 1:a006189

43. Serrano-Pozo A, Betensky RA, Frosch MP, Hyman BT (2016) Plaque-associated local toxicity increases over the clinical course of Alzheimer disease. Am J Pathol 186:375-384

44. Söderberg L, Dahlqvist C, Kakuyama H, Thyberg J, Winblad B, Näslund $J$ et al (2005) Collagenous Alzheimer amyloid plaque component assembles amyloid fibrils into protease resistant aggregates. FEBS J 272:2231-2236

45. Söderberg L, Bogdanovic N, Axelsson B, Winblad B, Näslund J, Tjernberg LO (2006) Analysis of single Alzheimer solid plaque cores by laser capture microscopy and nanoelectrospray/tandem mass spectrometry. Biochemistry 45:9849-9856

46. Strittmatter WJ, Saunders AM, Schmechel D, Pericak-Vance M, Enghild J, Salvesen GS et al (1993) Apolipoprotein E: high-avidity binding to $\beta$-amyloid and increased frequency of type 4 allele in late-onset familial Alzheimer disease. Proc Natl Acad Sci USA 90:1977-1981

47. Sturchler-Pierrat C, Abramowski D, Duke M, Wiederhold KH, Mistl C, Rothacher S et al (1997) Two amyloid precursor protein transgenic mouse models with Alzheimer disease-like pathology. Proc Natl Acad Sci USA 94:13287-13292

48. Suzuki N, Cheung TT, Cai XD, Odaka A, Otvos L Jr, Eckman C et al (1994) An increased percentage of long amyloid $\beta$ protein secreted by familial amyloid $\beta$ protein precursor ( $\beta$ APP717) mutants. Science 264:1336-1340

49. Tai LM, Balu D, Avila-Munoz E, Abdullah L, Thomas R, Collins N et al (2017) EFAD transgenic mice as a human APOE relevant preclinical model of Alzheimer's disease. J Lipid Res 58:1733-1755

50. Tanaka T, Wakabayashi T, Oizumi H, Nishio S, Sato T, Harada A et al (2014) CLAC-P/collagen type XXV is required for the intramuscular innervation of motoneurons during neuromuscular development. J Neurosci 34:1370-1379

51. Tomita T, Maruyama K, Saido TC, Kume H, Shinozaki K, Tokuhiro S et al (1997) The presenilin 2 mutation (N141l) linked to familial Alzheimer disease (Volga German families) increases the secretion of amyloid $\beta$ protein ending at the 42nd (or 43rd) residue. Proc Natl Acad Sci USA 94:2025-2030 
52. Urbanc B, Cruz L, Le R, Sanders J, Ashe KH, Duff K et al (2002) Neurotoxic effects of thioflavin S-positive amyloid deposits in transgenic mice and Alzheimer's disease. Proc Natl Acad Sci USA 99:13990-13995

53. Urlich JD, Ulland TK, Mahan TE, Nyström S, Nilsson KP, Song WM et al (2018) ApoE facilitates the microglial response to amyloid plaque pathology. J Exp Med 215:1047-1058

54. Vidal M, Morris R, Grosveld F, Spanopoulou E (1990) Tissue-specific control elements of the Thy-1 gene. EMBO J 9:833-840

55. Woltjer RL, Cimino PJ, Boutté AM, Schantz AM, Montine KS, Larson EB et al (2005) Proteomic determination of widespread detergent-insolubility including $A \beta$ but not tau early in the pathogenesis of Alzheimer's disease. FASEB J 19:1923-1925

56. Yamada K, Yabuki C, Seubert P, Schenk D, Hori Y, Ohtsuki S et al (2009) $A \beta$ immunotherapy: intracerebral sequestration of $A \beta$ by an anti-A $\beta$ monoclonal antibody 266 with high affinity to soluble $A \beta$. J Neurosci 29:11393-11398

57. Yamaguchi H, Hirai S, Morimatsu M, Shoji M, Ihara Y (1988) A variety of cerebral amyloid deposits in the brains of the Alzheimer-type dementia demonstrated by $\beta$ protein immunostaining. Acta Neuropathol 76:541-549

58. Yamaguchi H, Hirai S, Morimatsu M, Shoji M, Nakazato Y (1989) Diffuse type of senile plaques in the cerebellum of Alzheimer-type dementia demonstrated by $\beta$ protein immunostain. Acta Neuropathol 77:314-319

59. Yamamoto K, Tanei Zl, Hashimoto T, Wakabayashi T, Okuno H, Naka Y et al (2015) Chronic optogenetic activation augments $A \beta$ pathology in a mouse model of Alzheimer disease. Cell Rep 11:859-865

60. Yuan P, Condello C, Keene CD, Wang Y, Bird TD, Paul SM et al (2016) TREM2 haplodeficiency in mice and humans impairs the microglia barrier function leading to decreased amyloid compaction and severe axonal dystrophy. Neuron 90:724-739

\section{Publisher's Note}

Springer Nature remains neutral with regard to jurisdictional claims in published maps and institutional affiliations.
Ready to submit your research? Choose BMC and benefit from:

- fast, convenient online submission

- thorough peer review by experienced researchers in your field

- rapid publication on acceptance

- support for research data, including large and complex data types

- gold Open Access which fosters wider collaboration and increased citations

- maximum visibility for your research: over $100 \mathrm{M}$ website views per year

At BMC, research is always in progress.

Learn more biomedcentral.com/submissions 